This PDF is a selection from a published volume from the National Bureau of Economic Research

Volume Title: A History of Corporate Governance around the World: Family Business Groups to Professional Managers

Volume Author/Editor: Randall K. Morck, editor

Volume Publisher: University of Chicago Press

Volume ISBN: 0-226-53680-7

Volume URL: http://www.nber.org/books/morc05-1

Conference Date: June 21-22, 2003

Publication Date: November 2005

Title: The History of Corporate Ownership in Italy

Author: Alexander Aganin, Paolo Volpin

URL: http://www.nber.org/chapters/c10273 


\title{
The History of Corporate Ownership in Italy
}

\author{
Alexander Aganin and Paolo Volpin
}

\subsection{Introduction}

Recent contributions show that the Italian corporate governance regime exhibits low legal protection for investors and poor legal enforcement ( $\mathrm{La}$ Porta et al. 1998), underdeveloped equity markets (La Porta et al. 1997), pyramidal groups, and very high ownership concentration (Barca 1994). Arguably, due to these institutional characteristics, private benefits of control are high (Zingales 1994), and minority shareholders are often expropriated (Bragantini 1996). How did this corporate governance system emerge over time?

In this paper we use a unique data set with information on the control of all companies traded on the Milan Stock Exchange (MSE) in the twentieth century to study the evolution of the stock market, the dynamics of the ownership structure of traded firms, the birth of pyramidal groups, and the growth and decline of ownership by families.

We find that all our indicators (stock market development, ownership concentration, separation of ownership and control, and the power of families) followed a nonmonotonic pattern. The MSE showed more signs of development at the beginning and at the end of the century than in the middle of the century. Widely held pyramids were more common in 1947 and in 2000 than in 1987. Pyramidal groups and the separation of owner-

Alexander Aganin is manager at Cornerstone Research. Paolo Volpin is an assistant professor of finance at the London Business School.

We thank Daniel Wolfenzon (the discussant), Marco Becht, Luca Enriques, Andrea Goldstein, Ross Levine, Randall Morck, and participants at the Conference on the History of Corporate Ownership organized by the National Bureau of Economic Research and the European Corporate Governance Institute at Lake Louise (Canada) and at INSEAD. The views expressed in this paper do not represent in any way the views of Cornerstone Research. 
ship from control were more widespread in the 1980s than in either the 1940 s or in 2000. Family-controlled groups were more powerful in the middle of the century than at the beginning or at the end of it.

The results of our analysis can be explained as the joint effect of laws and politics on the Italian financial market. During the beginning of the century, Italian capitalism was characterized by a limited and indirect intervention of the government in the economy and in the stock market. The Great Depression forced the government to intervene on a much larger scale because the crisis led to the collapse of Italy's three main investment banks. Since then, the government has maintained a direct role in the economy by bailing out companies in trouble, as well as by controlling companies, especially in capital-intensive sectors.

Direct intervention by the state as an entrepreneur partially replaced and crowded out the role of the private sector in the accumulation of capital. Since the state took a direct and massive role in allocating capital, Italian legislators did not consider the improvement of investor protection important for Italy. This is at odds with the experience of countries such as the United States, where the government faced similar challenges to those of Italy but chose to intervene as a regulator of capital markets rather than as a substitute. In an environment with no regulatory reforms, and frequent direct intervention by the state, Italian stock market activity declined in the 1950s and 1960s to a level lower than that of the early twentieth century.

With low investor protection and underdeveloped capital markets, new entrepreneurs found it very expensive to go public. Conversely, incumbent groups thrived in the market by allying themselves with politicians. During the fascist regime, autarchy protected them from foreign imports. By the postwar period, family capitalism firmly controlled the Italian economy. Important families enjoyed both economic and political power, which was transmitted from generation to generation. New publicly traded family groups seldom emerged. When they did, it was always due to strong political connections.

In this environment the majority of Italian firms stayed away from the stock market, were closely held by the founders' families, and operated on a relatively small scale in niche markets. Family-controlled pyramidal groups and state-controlled conglomerates dominated the stock market. Because poor investor protection made Italian stock market unattractive, investors preferred to invest in government bonds rather than in equities.

To finance the costs of its active role in the economy, the government increased taxation and public debt. Eventually, public debt soared out of control, and in the 1990s the government engaged in a sweeping privatization program in an effort to reduce this debt. The government coupled the sale of assets with substantial improvement of the legal protection for minority shareholders. These changes made going public more appealing for 
private companies and benefited the stock market. With a more developed stock market came a greater demand for good corporate governance by investors, which imposed tighter constraints on family groups.

Currently, Italian capitalism is going through a very difficult transition period. Family groups, who were initially caught unprepared for the increased demand for good corporate governance, are slowly adapting to the rules of the international capital markets.

The structure of this paper is as follows. Section 6.2 briefly describes the institutional framework of Italian capitalism, focusing specifically on its legal and political environment. Section 6.3 focuses on the evolution of the stock market. Section 6.4 studies the dynamics of the ownership structure of traded firms. Family capitalism and the growth and decline of ownership by families are discussed in section 6.5. Section 6.6 concludes.

\subsubsection{Related Literature}

The paradigm in the literature on comparative corporate governance is the law and finance view, as developed by La Porta et al. (1998). This approach emphasizes that the protection of minority investors provided by the law is the key determinant of the corporate governance regime within a country. The argument is that investors will not provide equity to finance a firm unless they are confident of receiving a fair return from their investment. If shareholder protection is low, minority shareholders require a high return from their investment to compensate them for the high risk of expropriation by the management or by the controlling shareholder. Because external finance is more costly, ownership will be more concentrated and fewer companies will go public.

Several cross-country studies show that better legal protection of minority shareholders is associated with more developed stock markets ( $\mathrm{La}$ Porta et al. 1997), higher valuation (La Porta et al. 2002), greater dividend payouts (La Porta et al. 2000), lower concentration of ownership and control (La Porta, López-de-Silanes, and Shleifer 1999), lower private benefits of control (Dyck and Zingales 2004; Nenova 2003), lower earnings management (Leuz, Nanda, and Wysocki 2003), lower cash balances (Dittmar, Mahrt-Smith, and Servaes 2003), higher correlation between investment opportunities and actual investments (Wurgler 2000), and a more active market for mergers and acquisitions (Rossi and Volpin 2004).

This paper builds on this literature but looks at the time series implication by focusing on one country (Italy) over one century of history.

\subsection{Institutional Framework}

Over the century, several important political decisions affected the stock market and the regulatory environment. In this section, we briefly review 
the main political interventions in the economy, distinguishing between economic policy and legislation. ${ }^{1}$

\subsubsection{Economic Policy}

At the end of the nineteenth century, Italy was still lagging behind in the industrialization process. The absence of spontaneous industrialization led to the creation of substitute factors (Gerschenkron 1962) and specifically to the development of universal banks. Banca Commerciale Italiana and Credito Italiano were both established in 1894 with the backing of German capital and management.

The period from 1896 to 1914 was the first phase of intense industrialization in the country. The two banks provided financial resources and managerial skills to the most important entrepreneurial initiatives, including Breda (train engines), FIAT (automobiles), and Montecatini (mining), and facilitated the birth of essential electrical and steel sectors.

However, universal banks were not able to bear the entire weight of the industrialization process. Already in 1887, government intervention was needed to rescue a large steel company, Terni, and its lenders from bankruptcy. In 1911, the government and the largest banks rescued the entire steel sector. In 1923 the Bank of Italy bailed out the largest company of the time, Ansaldo, and its two major creditors, Banca Italiana di Sconto and Banco di Roma.

These events indicate that Italian capitalism required the continuous assistance and involvement of the government from the start. The Great Depression forced the government to intervene on a much larger scale. The financial crisis led to the collapse of Italy's three main investment banks: Banca Commerciale, Credito Italiano, and Banco di Roma. As a result, in 1933 the government created a new agency, the Instituto per la Ricostruzione Industriale (IRI), to manage the large portfolio of companies previously controlled by the three banks.

Since that time, the Italian state has maintained a direct presence in the economy as the controlling shareholder of profit-oriented firms. The role of the state in the economy grew larger with the advent of the Republic. Instead of limiting its interventions to bailing out troubled companies, the state began acquiring sound companies and directly investing in all sectors of the economy. Due to its increased involvement in the Italian economy, the government created a second agency, named the Ente Nazionale Idrocarburi (ENI), in 1952. The ENI coordinated state-owned companies operating in the chemical, oil, and mining sectors. The government formed other institutions in 1962 (Efim) and in 1972 (Gepi) to direct state economic intervention in Southern Italy. All of these agencies were indepen-

1. The focus here is on policymaking rather than political regimes, which also changed dramatically during the twentieth century. Until 1923, Italy was a constitutional monarchy; from 1923 to 1945, it was a dictatorship. Since the end of the Second World War, Italy has been a democracy. 
dent of one another. In principle, they were managed as profit-oriented corporations, though they could rely on financial assistance from the Treasury if they ran into deficits. Their presidents had very strong personalities and ample opportunities to take advantage of their power. ${ }^{2}$ Over its life from 1933 to 2000 (IRI was liquidated in June 2000), IRI acquired fortytwo traded companies, did twenty-six carve-outs of subsidiaries, delisted forty, and sold twenty-eight companies. ENI acquired eight companies, did six carve-outs of subsidiaries, delisted five, and sold six companies.

The government's decision to nationalize the electrical industry in early 1960 s proved to be an important event for the Italian stock market. Political goals determined such a decision. The Christian Democrats, in power since the end of the war, had seen their share of electoral consensus steadily decrease from 49 percent in 1948 to around 38 percent by 1958. After failing to co-opt parties that were ideologically closer, to retain power, the Christian Democrats resorted to attracting the Socialist Party, which controlled about 8 percent of the seats in Parliament. As a condition of their support, the socialists required the nationalization of the electric industry. ${ }^{3}$

The fate of the electric sector had been set since the end of the 1950s. The political debate concerned whether to acquire only the assets from the electric companies, or to acquire the companies themselves. The decision to pay companies for their assets was made on June 17, 1962, and became law on December 12, 1962. The government left other decisions about the future of the companies to their shareholders. ${ }^{4}$

The 1962 nationalization had important implications for the stock market and the entire economy. The electrical groups played a crucial role in the stock market: not only did they represent approximately one-third of the total market capitalization, but they also functioned as a nucleus of economic and political power to a large extent free of government control. The first effect of the nationalization was a sequence of mergers inside these groups, later followed by mergers among these groups. Rather than paying out the proceeds to shareholders, the groups invested the payments obtained from the nationalization. Incompetent or dishonest managers ${ }^{5}$

2. The second president of ENI, Eugenio Cefis, serves as one extreme example. At the beginning of the seventies, he used his power to push ENI through an intense period of acquisitions and suspicious financial operations. Some years later he was found guilty of corruption. For a detailed discussion see Barca and Trento (1997).

3. Like Labour in the United Kingdom and Socialists in France, who implemented similar projects just after the war, Italian Socialists wanted to reduce the rents enjoyed by the companies operating in that industry.

4. The railways' nationalization at the beginning of the century served as a model for this plan. The compensation paid to railway companies on that occasion provided them with the resources to invest in and give birth to the electric industry.

5. A good example is the merger in 1964 between SADE, a former electric company, and Montecatini, a chemical company. As reported by Scalfari and Turani (1974), Vittorio Cini, the CEO of SADE, negotiated a very poor deal for SADE's shareholders in exchange for a seat on the board of directors of Montecatini for himself. 
channeled most of the resources toward the chemical industry, giving birth to Montedison, which soon also came under government control (ENI). However, investing in the chemical industry proved unprofitable in a country with limited natural resources. As a result, the financial resources provided by the government as a compensation for the forced nationalization ended up almost entirely wasted.

State-owned enterprises contributed significantly to the growth of the country in the 1950s and 1960s (Barca and Trento 1997). However, over time they became a burden for economic growth because of weak managerial incentives, soft-budget constraints, inefficient production technologies, and misallocation of resources. The government financed these losses mainly with public debt. At the beginning of the 1990s, public debt soared out of control. Under pressure from the European Union, Italy's high level of debt forced the government to engage in a sweeping privatization program (see Goldstein 2003).

The extent of product market competition in Italy also changed throughout the century. The absence of antitrust legislation until $1991 \mathrm{im}-$ plied that large companies enjoyed unlimited market power until that time. Most families whose companies traded on the stock market financed the expansion of their empires with the large profits achieved from monopolistic rents in their core sector (the cases of Agnellis, Pesentis, and Pirellis are discussed in section 6.5).

Because of the government's direct intervention the extent of international competition followed a nonmonotonic pattern. The beginning of the twentieth century saw a trend of increasing market integration across European economies. By 1930 European economies were effectively truly interdependent. The trend waned after the Great Depression with the reemergence of nationalist isolationism, the introduction of foreign exchange controls, and the abolition of external convertibility.

Effectively, Italy remained in an autarkic regime until 1958, when it joined the European Economic Community (EEC). Since then, product markets and capital markets have slowly liberalized, allowing foreign competition. The EEC directives first imposed a liberalization of product markets, and later a liberalization of the capital markets as well (see Battilossi 2000). Not until 1990 had all constraints on cross-border transactions effectively been lifted.

\subsubsection{Legal and Regulatory Environment}

Over the sample period analyzed in this paper, the legal environment in Italy and, consequently, the degree of investor protection afforded by the law has also changed considerably. Table 6.1 lists in chronological order the major regulatory events affecting traded companies and financial markets. All events listed in the table occurred either before the Second World War or after 1974. This suggests us to divide the century into three subperiods, 
Aug. 4, 1913

Apr. 8, 1974

Mar. 31, 1975

May 17, 1991

Nov. 14, 1991

Feb. 12, 1992

Feb. 24, 1998

Mar. 16, 1942

Jan. 30, 1979

June 5, 1986

Mar. 12, 1936

Sept. 1, 1993

Mar. 16, 1942

June 7, 1974

Mar. 31, 1975

June 4, 1985

Apr. 9, 1991

Feb. 24, 1998

Mar. 23, 1983

Jan. 2, 1991

Jan. 27, 1992

Aug. 14, 1993

July 23, 1996

Feb. 24, 1998
Stock Exchange

Regulation of stockbrokers: banks cannot engage in trading on the stock market.

Creation of CONSOB, agency in charge of the supervision over the stock markets.

Definition of CONSOB's powers.

Insider trading law.

Regulation of disclosure requirements by companies offering securities to the public.

Takeover law: mandatory bid rule.

Passivity rule: managers cannot fight against a takeover without shareholder approval (legge Draghi).

\section{Bankruptcy code}

Bankruptcy Law. The main procedures for non-state-owned firms are: liquidation (fallimento) or reorganization (amministrazione controllata or concordato preventivo). State-owned companies are subject to a third procedure called liquidazione coatta amministrativa.

Special procedure (amministrazione straordinaria) for large firms (legge Prodi).

Simplification of the procedure for state-owned companies.

\section{Banking}

Delegation to the Bank of Italy of the supervision over the banking sector. Separation between commercial and investment banks: only the second group can engage in long-term lending and can own equity stakes in nonfinancial companies.

New law on banking and lending. Universal banking is allowed.

\section{Information disclosure by traded companies}

New commercial code: Shares with multiple votes are prohibited and cross-shareholdings are limited.

New disclosure requirements. New limits to cross-shareholdings. Listed companies can issue nonvoting shares ("savings shares").

External auditing required for the annual report.

Removal of a restriction to the ability to trade shares (clausola di gradimento).

Consolidated balance sheet required for groups.

Strengthening of minority shareholders' rights (legge Draghi).

\section{Institutional investors}

Open-end mutual funds are allowed to operate and are subject to

CONSOB's supervision.

Regulation of institutional investors.

Definition of disclosure and accounting requirements for mutual funds.

Authorization to the creation of close-end funds.

Regulation of mutual funds and financial intermediaries.

New law on financial intermediation.

Notes: This table lists the most important regulatory acts affecting investor protection in Italy. The events are classified into five categories depending on whether they are mostly relevant for the stock exchange, the bankruptcy procedure, the banking sector, information disclosure by traded companies, or institutional investors. The main feature of each regulatory act is briefly described. 
1900-1941, 1942-1973, and 1974-2000, each characterized by an increasing degree of investor protection.

In the first subsample, the stock market was virtually self-regulated. Firms could issue shares with multiple votes and use cross-shareholdings without limitation. Until the Bank Law of 1936 no limitations existed on banks' abilities to own industrial companies, lend money for both shortand long-term periods, underwrite security issues, and hold deposits. Effectively, banks served the role of today's venture capitalists, investment banks, and commercial banks. There was only one bankruptcy procedure, which consisted of a straight liquidation. Though legally allowed to incorporate as joint-stock companies-società anonime - since 1865, only few large firms took advantage of limited liability. The Commercial Code of 1882 required the approval of an annual report by shareholders but not the extent of information disclosure.

During the entire second period (1942-1973), laws introduced at the beginning of the period under the fascist regime regulated traded companies and financial markets. The laws included the Bank Law (1936), the Civil and Commercial Code (1942), and the Bankruptcy Law (1942). These laws improved shareholder protection in limited-liability companies. Companies were required to provide some minimal amount of information on their performance in annual reports for shareholders. In an attempt to curb cross-shareholdings, controlled companies could no longer exercise the voting rights of shares owned in the holding company. The Bankruptcy Law allowed creditors to opt for a form of reorganization as an alternative to straight liquidation. The Bank Law prohibited universal banking and prevented banks from holding equity stakes in nonfinancial firms. Commercial banks could engage mainly in short-term lending.

This set of laws, designed for a small economy in which the capital markets had a marginal role (as they did in Italy in the 1930s), gradually became obsolete and unable to address the needs of a developed country competing in international markets. For instance, the company law did not draw any distinction between traded and nontraded companies, imposing the same set of rules on both. No specific rules existed regarding information disclosure by a traded company, and no specific agency was in charge of stock market supervision. As a result, in the 1960s the balance sheets of large companies like Edison, Pirelli, and Snia Viscosa did not disclose basic items such as sales (Amatori and Brioschi 1997). In theory the stock market was free to set its own rules, but without any enforcement power, it was effectively unregulated.

In 1974, the legislature finally broke its thirty-year-long neglect of the stock market by creating CONSOB, the agency in charge of supervising the stock market, and by drafting a set of disclosure requirements explicitly created for traded companies. The Italian government modeled CONSOB on the Securities Exchange Commission in the United States. It took 
the government a year to define CONSOB's powers and another year for CONSOB to become operational. It took much more time for the power and relevance of CONSOB to become real.

At the same time, the legislators drafted specific requirements for traded companies to stimulate investment in the stock market by the general public. To this end, disclosure requirements were introduced in 1974 and traded companies were allowed to issue nonvoting shares ("savings shares"). Although these shares did not provide any voting rights, they entitled the owner to a higher dividend than ordinary shares. As suggested by their name, savings shares were deemed appropriate for unsophisticated investors. In 1975, the government imposed external auditing of the balances of traded companies as a requirement and also introduced new accounting rules for statements of financial companies, banks, and insurance companies. Since 1974, the acquisition of more than 2 percent of the voting rights of a traded company must be reported to CONSOB within fortyeight hours (since 1992, this information must be disclosed to the public).

The 1990s proved a period of very intense legislation, largely due to the European Community's pressure to harmonize stock market regulation within Europe. In 1991 came the requirement of consolidated balances for groups; in 1992 came the takeover law. At the same time, regulations by CONSOB in 1991 and 1992 imposed information disclosure on mutual funds. ${ }^{6}$ These requirements increased the transparency of the ownership structure of traded companies. In 1991, the Italian government enacted its first antitrust law.

Even with these important improvements, in 1994 Italy still ranked among the lowest of the industrial countries in legal protection for investors among the industrialized countries (La Porta et al. 1998). Antidirector rights, their index of shareholder protection, equaled one out of six for Italy. ${ }^{7}$ Despite all of the protections put into place, the legislation did not sufficiently protect small shareholders from expropriation by controlling blockholders. In fact, the regulation of groups of companies and the takeover law both contained loopholes, such as the limited protection offered to the owners of nonvoting shares. Moreover, minority shareholders had too little power to protect themselves. For example, 20 percent of the capital was needed to call a shareholder meeting, a very high threshold to meet. Shares had to be deposited in a bank in order to be voted, and

6. Mutual funds were allowed to operate since 1983.

7. The index is formed by adding one when (a) the country allows shareholders to mail their proxy vote to the firm, (b) shareholders are not required to deposit their shares prior to the general shareholders' meeting, (c) cumulative voting or proportional representation of minorities in the board of directors is allowed, (d) an oppressed-minorities mechanism is in place, (e) the minimum percentage of share capital that entitles a shareholder to call for an extraordinary shareholders' meeting is less than or equal to 10 percent (the sample median), or (f) shareholders have preemptive rights that can be waived only by a shareholders' vote. According to La Porta et al. (1998), in 1994 Italian shareholders had only preemptive rights. 
there was no vote by mail. These and other rules made it costly for small shareholders to vote.

In 1998, important steps were taken toward better legal protection for investors with the so-called Legge Draghi (Draghi's Law), named for its leading drafter. The law prohibited managerial opposition to takeovers without shareholder approval. If evaluated in terms of the index of shareholder protection developed by La Porta et al. (1998), the impact of this law was an improvement in shareholder protection from one to five. Specifically, the law reduced the threshold to call a shareholder meeting to 10 percent, it also corrected the loopholes in the takeover law, and it gave minority shareholders more rights to voice their opinions. ${ }^{8}$

\subsection{The Stock Market}

In 1808, the Napoleonic government established the Milan Stock Exchange as a market for securities and commodities. As noticed by Baia Curioni (1995) and De Luca (2002), unlike the markets in London and Amsterdam, the MSE was not created spontaneously by the financial operators of the time but was created by the government. Possibly for this reason, the market did not start to serve as the main financial center in Milan until the 1850s. At that time, the only traded securities were government bonds. In 1859, the first shares (of a railway company, Societa' delle Strade Ferrate Lombardo Veneto) were listed. This first traded company was followed by many banks and a few industrial companies. In 1873, shares of twenty-five companies were traded on the MSE.

At that time, the MSE was a local exchange. Stock exchanges of similar size were set up in several other Italian cities. In 1873, the MSE ranked second for trade volume after Genoa, but before Turin, Florence, Rome, and Naples.

The absence of regulation offered speculators wide opportunities to profit and kept uninformed investors (and liquidity) away. The turning point for the MSE came with the intense industrialization push between 1895 and 1907. In twelve years, the number of traded companies jumped from 27 to 171. The intense activity of the universal banks, Banca Commerciale and Credito Italiano, caused the boom of the stock market. The two banks helped many entrepreneurs raise capital for their projects by setting up limited-liability companies and selling shares on the stock market. According to Bonelli (1971), in 190772 percent of the equity of all limitedliability firms was traded on stock markets.

The stock market boom lasted only for a few years. According to Sicil-

8. According to Enriques (2003), for the period 1942-93 the correct score on antidirector rights for Italy is 2 rather than 1 because proportional representation on the board was an option available to any firms since 1942 . 
iano (2001), Banca Commerciale, Credito Italiano, and the other banks probably inflated stock prices by purchasing shares while borrowing against their equity stakes in traded firms. An increase in the short-term interest rates in 1907 increased the banks' costs of sustaining prices. The resulting liquidity crisis forced the banks first to stop buying shares and then to sell their stakes in the traded firms. In turn, the sale of their stakes put downward pressure on prices, thereby exacerbating the crisis. This major financial crisis lasted until 1914.

The crisis of 1907 spurred a regulatory intervention by the government. After years of debates, in 1913 a new law prohibited banks from trading shares of companies listed on the stock exchanges. According to Baia Curioni (1995), this regulatory intervention proved the major cause of the underdevelopment of the Italian stock market. Siciliano (2001) disagrees, however, because France, the United Kingdom, and the United States introduced similar laws without damaging effects on the stock market.

With no doubts, the crisis of 1907 profoundly impacted small investors. A good example is FIAT, the automotive company at the core of the Agnellis' empire, which was then traded on the Turin stock exchange. The company operated in a glamorous (for the time) sector, which had tremendous growth opportunities and had generated a lot of excitement in the investing public. In 1906, FIAT's stock traded at Lit 2,000 per share (a priceearnings ratio of twenty-eight). The collapse of the stock market brought the share price down to Lit 17 in just a few months. The creditors stepped in to rescue the company from the brink of liquidation. A pool of banks, led by Banca Commerciale, cancelled existing shares, approved a new share issue, and gave back the control of the company to Giovanni Agnelli, the chief executive officer (CEO) before the crisis.

A thousand small shareholders, who had seen the value of their shares disappear, sued the managers of FIAT for accounting irregularities and price manipulation. The trial received significant attention because of Giovanni Agnelli's close friendship with Prime Minister Giovanni Giolitti. The trial lasted five years and concluded with the declaration that Agnelli was not guilty of any wrongdoing.

By 1918, the MSE became Italy's main stock exchange, although by then the phase of strong development had ended. Figure 6.1 plots the number of companies traded on the MSE over the twentieth century as a raw number and as a fraction of the population (in millions). La Porta et al. (1997) suggest that the latter measure is a good indicator of stock market development. The figure shows a highly nonmonotonic pattern of development. The strong growth of the beginning of the century lasted until 1914, and a period of limited growth followed until 1930.

Figure 6.1 shows that the Great Depression brought about a drastic reduction in the number of traded companies. With the nationalization of the 


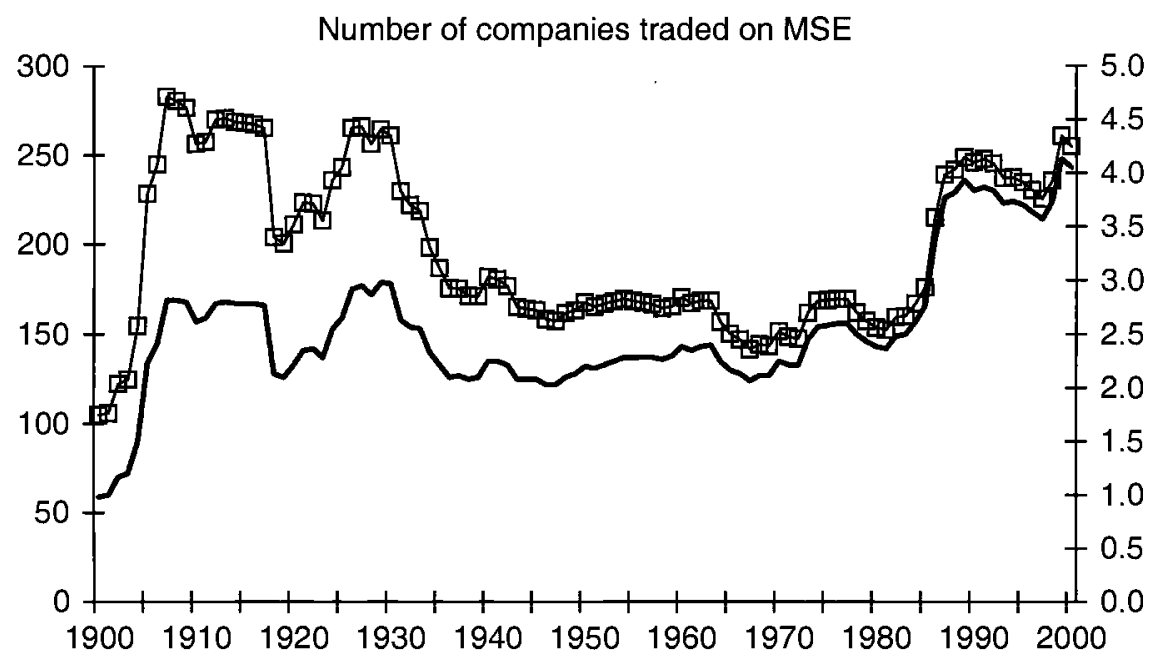

- Number of traded companies $\square$ Divided by population in milions

Fig. 6.1 Evolution over time of the number of companies traded on the MSE

Notes: The continuous line represents the raw number and is measured against the axis on the left. The dotted line, whose values are shown on the right axis, represents the number of firms divided by the population in millions. The time series of the population is obtained from Rey (1991) and Datastream.

universal banks and the creation of IRI, the stock market became secondary in the process of allocation of capital toward investment.

One important cause of the end of the period of growth for the stock market was the lack of protection for minority shareholders. There was a general market perception that universal banks and managers like Agnelli used the investment boom early in the century to pump and dump their shares. Further, the drastic increase of dividend taxation at company and personal level introduced by the fascist government made investment in the stock market even less attractive (Aleotti 1990).

The situation improved marginally after the Second World War. In this period, a total of ten local stock markets existed in Italy. In 1962, the nationalization of the electric industry caused a pronounced reduction in the total market capitalization as shown in figure 6.2, which plots the total market capitalization as a percentage of the gross national products over time. It is interesting to note that the nationalization itself was not associated with a decrease in market capitalization. To the contrary, total market capitalization increased considerably while the politicians debated the new law. It was the subsequent wasting of resources in negative net present value (NPV) projects brought the market down.

The slow decline of investment in the stock market continued until the middle of the seventies, when the government established CONSOB (in 


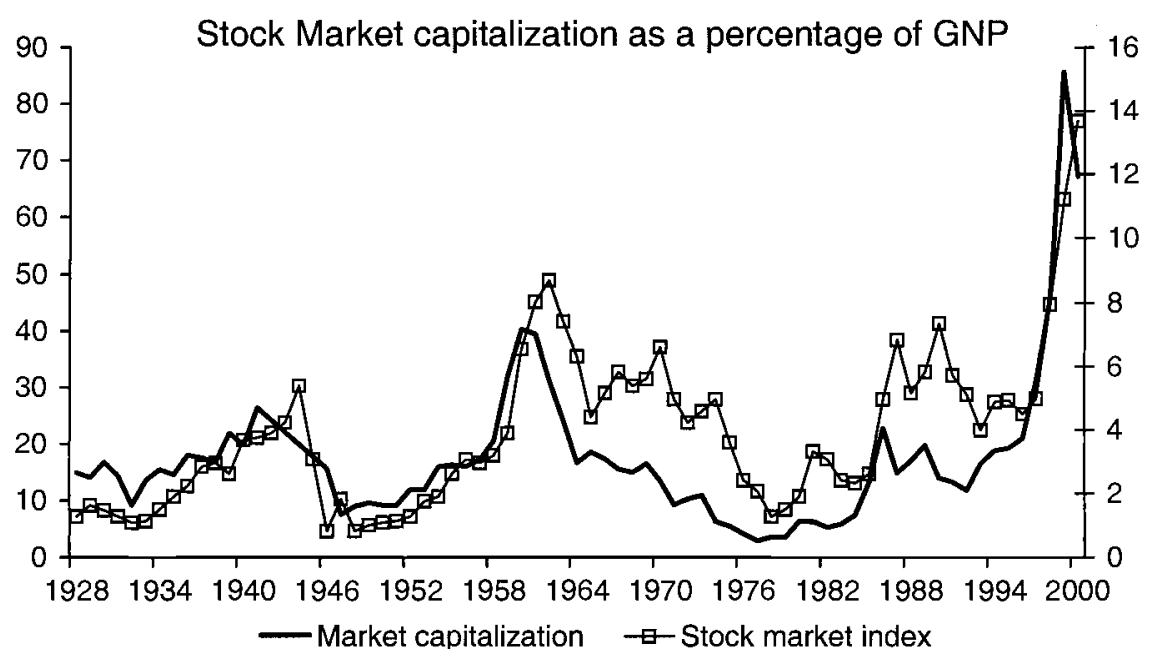

Fig. 6.2 Evolution over time of the market capitalization of the MSE

Notes: The continuous line is the total market capitalization as a percentage of the gross national product (GNP) and is measured against the axis on the left. The time series of the GNP is obtained from Rey (1991) and Datastream. The dotted line, whose values are shown on the right axis, is the index of stock prices on the MSE. The index is from Dimson, Marsh, and Staunton (2001); it measures the evolution of stock prices in real terms and is normalized so that it takes the value 1 in 1900 .

1974). Substantial growth of the stock market began with the introduction of the mutual funds in 1983. In the three years between 1983 and 1986, mutual funds raised and invested about $\$ 6$ billion in the stock market (De Luca 2002). These new available resources induced many companies to go public. Between 1983 and 1989, the number of companies traded on the stock market jumped up more than 50 percent. However, most of the new listings were subsidiaries of traded companies going public to take advantage of the stock market boom (Pagano, Panetta, and Zingales 1998).

The real push in stock market development came after the start of the recent privatization program. In 1995 the stock market capitalization was only 20 percent of the gross national product (GNP). In 2000 it had grown to 70 percent. The increase in market capitalization was due to the listing of huge government-controlled companies, such as ENI (chemicals), INA (insurance), IMI (banking), and ENEL (energy), and the sale of the government-owned control stakes in already-listed banks, such as Comit, Credit, and BNL. These privatizations went hand in hand with regulatory reforms, such as the law on insider trading in 1991, the takeover law in 1992, and Draghi's Law in 1998.

With a total market capitalization in 2000 of 70 percent of GNP, the MSE is comparable to stock markets in other developed countries. However, the Italian stock market does not mirror the Italian economy. Large 
corporations and financial institutions dominate the stock market, while the greatest majority of firms shy away from the stock market.

\subsubsection{Investor Protection and Stock Market Development}

According to La Porta et al. (1998), stock market development should be positively correlated with shareholder protection. The intuition is that investors will not provide equity to finance a firm unless they are confident of receiving a fair return from their investment. If shareholder protection is low, minority shareholders require a high return from their investment to compensate them for the high risk of expropriation by the management or controlling shareholder. The high required rate of return makes external finance costly and leads fewer companies to go public. Consistent with this prediction, La Porta et al. (1997) find that in the 1990s countries with stronger shareholder protection were characterized by larger stock markets. ${ }^{9}$ This finding results from a cross section of countries, but it should also hold with time series data for a single country.

To test this prediction we compare the stock market development across the three subsamples identified in section 6.2.2, which display significant differences in investor protection. As discussed before, the period 1900-41 had the lowest level of investor protection; 1974-2000 exhibited the highest investor protection of the periods; an intermediate level of investor protection characterized the years between 1942 and 1973. As alternative measures of stock market development, we use the ratio of the number of traded companies to population (in millions) and market capitalization as a percentage of GNP.

As shown in column (1) of table 6.2, the indicators for the periods with the lowest and the highest investor protection are both positive and statistically significant in the regression explaining the variation of the number of traded companies scaled by population during the century. This implies that the subsample 1942-73 is characterized by higher investor protection but lower stock market development than the subsample 1900-41. The comparison between the second (1942-73) and third (1974-2000) subsamples is instead fully consistent with the theory: higher investor protection accompanies more financial development. The results do not change in column (2), where we add the stock market index to control for firms' opportunism in their decision to go public. ${ }^{10}$

In column (3), we use the index of antidirector rights proposed by La Porta et al. (1998). We follow Enriques (2003) and compute the evolution of this index from 1900 to 2000 . As discussed in footnote 8 , the index takes a value of 1 before 1942, equals 2 for the 1942-93 period, increases to 3 in

9. Shleifer and Wolfenzon (2002) formally model this theory.

10. Pagano, Panetta, and Zingales (1998) find that market timing is an important determinant of the going-public decision by Italian companies. 


\begin{tabular}{|c|c|c|c|c|c|c|}
\hline \multirow[b]{2}{*}{ Dependent variable } & \multicolumn{3}{|c|}{$\begin{array}{l}\text { No. of traded companies } \\
\text { scaled by population }\end{array}$} & \multicolumn{3}{|c|}{$\begin{array}{l}\text { Market capitalization } \\
\text { divided by GNP }\end{array}$} \\
\hline & (1) & (2) & (3) & (4) & (5) & (6) \\
\hline Constant & $\begin{array}{l}2.68 * * * \\
(0.11)\end{array}$ & $\begin{array}{l}2.34 * * * \\
(0.17)\end{array}$ & $\begin{array}{l}4.80 * * * \\
(0.34)\end{array}$ & $\begin{array}{l}17.15^{* * *} \\
(1.67)\end{array}$ & $\begin{array}{l}-0.47 \\
(3.42)\end{array}$ & $\begin{array}{l}26.06^{* * *} \\
(3.20)\end{array}$ \\
\hline $\begin{array}{l}\text { Dummy } 1900-1941=\text { lower } \\
\text { investor protection }\end{array}$ & $\begin{array}{l}0.98 * * * \\
(0.15)\end{array}$ & $\begin{array}{l}1.18 * * * \\
(0.17)\end{array}$ & & $\begin{array}{c}-0.49 \\
(1.99)\end{array}$ & $\begin{array}{l}7.83^{* * * *} \\
(2.19)\end{array}$ & \\
\hline $\begin{array}{l}\text { Dummy } 1974-2000=\text { higher } \\
\text { investor protection }\end{array}$ & $\begin{array}{l}0.75^{* * *} \\
(0.17)\end{array}$ & $\begin{array}{l}0.69^{* * *} \\
(0.16)\end{array}$ & & $\begin{array}{c}0.96 \\
(4.12)\end{array}$ & $\begin{array}{l}-2.57 \\
(2.31)\end{array}$ & \\
\hline Stock market index & & $\begin{array}{l}0.08 * * * \\
(0.03)\end{array}$ & $\begin{array}{c}0.03 \\
(0.03)\end{array}$ & & $\begin{array}{l}4.44^{* * * *} \\
(0.80)\end{array}$ & $\begin{array}{l}2.54 * * * \\
(0.49)\end{array}$ \\
\hline Antidirector rights & & & $\begin{array}{l}-1.50 * * * \\
(0.26)\end{array}$ & & & $\begin{array}{l}-19.61 * * * \\
(3.20)\end{array}$ \\
\hline (Antidirector rights) $^{2}$ & & & $\begin{array}{l}0.27^{* * * *} \\
(0.04)\end{array}$ & & & $\begin{array}{l}4.44^{* * *} \\
(0.83)\end{array}$ \\
\hline$R^{2}$ & 0.31 & 0.36 & 0.23 & 0.01 & 0.61 & 0.76 \\
\hline No. of observations & 101 & 101 & 101 & 69 & 69 & 69 \\
\hline
\end{tabular}

Notes: Stock market development (the dependent variable) is measured alternatively as the number of traded companies divided by population in millions (in columns [1] and [2]) or market capitalization as a percentage of GNP (in columns [3] and [4]). Independent variables are: a dummy variable that takes value 1 in the years from 1900 to 1941 and 0 otherwise to represent the period with relatively lower investor protection; a dummy variable that takes value 1 in the years from 1974 to 2000 and 0 otherwise to represent the period with relatively higher investor protection; and the stock market index. The latter is obtained from Dimson, Marsh, and Staunton (2001), is measured in real terms, and is normalized so that it takes value $1 \mathrm{in} 1900$. Antidirector rights measure the degree of shareholder protection. It is produced by La Porta et al. (1998) and extended over time for Italy by Enriques (2003). OLS regressions: robust standard errors are in parentheses.

***Significant at the 1 percent level.

1994, and jumps to 5 from 1998. The results in column (3) confirm a strong nonlinear relation between stock market development and investor protection. Starting from a low level of investor protection (below 2), an increase in investor protection reduces stock market development. The opposite happens if we start from a high level of investor protection (above 3 ).

In columns (4) to (6), we use the market capitalization as a percentage of GNP as an alternative measure of stock market development. The results in column (4) indicate that there is no significant difference in stock market development across the three subsamples. When we add the stock market index, in column (5), we find that the period 1900-41 (the period with the lowest investor protection) is characterized by higher stock market development than the later periods. The results in column (6) confirm the Ushaped relation between stock market development and investor protection. Overall, the findings in table 6.2 suggest that there is no monotonic relationship between investor protection and stock market development, which is difficult to reconcile with the law and finance view. 


\subsubsection{Discussion}

An important missing variable in the regressions reported in table 6.2 is enforcement. La Porta et al. (1998) and Bhattacharya and Daouk (2002) show that enforcement is a crucial explanatory variable in a cross-country setting. To evaluate the effect of enforcement, Enriques (2003) analyzes the quality of Italian corporate judges' decisions in 123 cases between 1986 and 2000 . He finds that judges tend to be biased in favor of corporate insiders and very formalistic in their arguments. Moreover, he finds no evidence that judges take into account the impact of their decisions on the incentives and the behavior of corporations and managers. These findings confirm the evidence in La Porta et al. that the quality of legal enforcement in Italy is very low, as measured by rule of law and judicial efficiency. Unfortunately, we do not have a time series measure of enforcement that we can use in our study.

A second variable missing from the regressions in table 6.2 is politics. A growing academic literature argues that a country's financial development is the outcome of ideology and the economic interests of voters and pressure groups. Rajan and Zingales (2003) argue that the stock market can be either fostered or hampered by government action, depending on the balance of powers between pressure groups. Pagano and Volpin (2001) and Biais and Perotti (2002) argue that state intervention in the economy should be negatively correlated with financial development, because the state acts as a substitute for financial markets. One proxy for the government's intervention in the economy is the number of government-controlled companies on the stock market as a percentage of the total number of traded companies.

Figure 6.3 plots the evolution of stock market development and public ownership of traded companies over time. The initial period of growth ended with the Great Depression and was followed by a long period of stagnation, which lasted until the 1980s. Only in 1985 did the number of companies on the stock market exceed the level it had reached in 1930. When combined with the observation that gross domestic product increased by 200 percent in real terms between 1950 and 1980, these data emphasize what little relevance to the Italian economy the stock market has had since the Great Depression. While the stock market stagnated, the role of the government increased. From 1950 to 1980, between 15 and 20 percent of traded companies in Italy were controlled by the government. The correlation between the two series is -70 percent.

According to Rajan and Zingales (2003), another important variable to explain stock market development is openness, defined as the ratio of the sum of imports and exports to GNP. Their argument is that a country opens to trade to take advantage of growth opportunities. To finance these investment opportunities, incumbents needs to raise capital and therefore 


\section{Stock market development and State ownership}

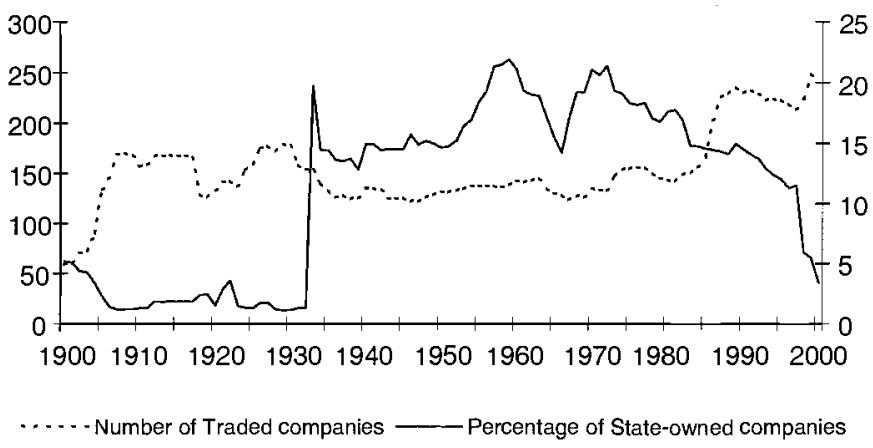

Fig. 6.3 Evolution of the presence of the government on the stock market

Notes: The variable called government-controlled traded firms is the percentage of traded companies under government control. It is plotted as a continuous line, and its value is shown on the right axis. The dotted line (measured against the left axis) is the number of companies traded on the MSE.

demand more financial development. As discussed in section 6.2.2, Italy was relatively open to trade at the beginning of the century, became an autarchy in the 1930s, and opened up to trade again in the late 1950s.

In table 6.3, we add the measures of government intervention and openness to the legal variables. In column (1), we use the number of traded companies as a fraction of population as the dependent variable. We find that only the political variable is significant and has the predicted negative sign. This result is also robust across specifications. We obtain the same result in column (2), where financial development is measured as market capitalization over GNP. In this specification, the index of antidirector rights is also statistically significant and positive. This result suggests that once we control for government intervention investor protection has the predicted positive impact on stock market development. ${ }^{11}$ Contrary to Rajan and Zingales (2003), openness is negatively correlated with financial development. A possible reason is that openness is positively correlated with GNP, which is at the denominator in this measure of financial development.

In column (3), we look at the number of independent public offerings (IPOs) as an alternative measure of financial development. The fraction of government-controlled traded firms is negatively correlated with the number of IPOs. Also, as in column (2), an increase in investor protection is associated with an increase in the number of IPOs. Consistent with Rajan and Zingales (2003), openness is positively correlated with the number of IPOs. The evidence in column (3) is consistent with all three channels disobservations used in column (2), not reported, we obtain the same results as in column (1). 
Table 6.3

Investor protection, openness and politics

\begin{tabular}{lccc}
\hline & $\begin{array}{c}\text { No. of traded } \\
\text { companies scaled } \\
\text { by population }\end{array}$ & $\begin{array}{c}\text { Market } \\
\text { capitalization } \\
\text { divided by GNP }\end{array}$ & $\begin{array}{c}\text { No. of } \\
\text { IPOs } \\
\text { Dependent variable }\end{array}$ \\
\hline Constant & $3.78^{* * *}$ & $(2)$ & $(3)$ \\
Antidirector rights & $(0.17)$ & $17.41^{* * *}$ & 2.62 \\
& -0.04 & $(2.65)$ & $(2.19)$ \\
Government-controlled & $(0.07)$ & $8.50^{* * *}$ & $2.46^{* *}$ \\
traded firms (\%) & $-0.08^{* * *}$ & $(2.07)$ & $(1.10)$ \\
Openness & $(0.01)$ & $-0.70^{* * *}$ & $-0.46^{* * *}$ \\
& 0.54 & $(0.17)$ & $(0.12)$ \\
Stock market index & $(0.35)$ & $-60.23^{* * *}$ & $11.87^{*}$ \\
& $0.09^{* * *}$ & $(8.71)$ & $(6.21)$ \\
$R^{2}$ & $(0.02)$ & $3.41^{* * *}$ & 0.49 \\
No. of observations & 0.49 & $(0.42)$ & $(0.36)$ \\
\hline
\end{tabular}

Notes: The dependent variable is the number of traded companies divided by population in millions (in column 1), the stock market capitalization as a percentage of GNP (in column 2), and the number of IPOs (in column 3). Independent variables include the index of antidirector rights, as produced by LLSV (1998) and extended over time for Italy by Enriques (2003); the number of government-controlled companies as a percentage of all traded companies; openness, which is the sum of exports and imports of goods divided by GNP; and the stock market index. The latter is obtained from Dimson, Marsh, and Staunton (2001), is measured in real term, and is normalized so that it takes value 1 in 1900. OLS regressions: robust standard errors are in parentheses.

***Significant at the 1 percent level.

**Significant at the 5 percent level.

*Significant at the 10 percent level.

cussed above. Once we control for the other channels, stock market development increases with investor protection and openness and decreases with government intervention.

One concern with the results on the political variable is about its interpretation. We argue that state intervention in the economy should be negatively correlated with financial development because the state acts as a substitute for financial markets. However, the negative impact of government intervention on the number of traded companies could be more direct and less interesting. If the government fully nationalizes one traded company, the number of traded companies mechanically decreases by one unit. If this is the case, we expect to see delisting following an increase in the fraction of government-owned companies. We did not find such a relationship in the data (not reported).

The results in this section leave a key question unanswered: How did Italian companies finance the extraordinary economic growth of 1950s and 1960 s if the stock market was stagnant? Figure 6.4 suggests that the growth 


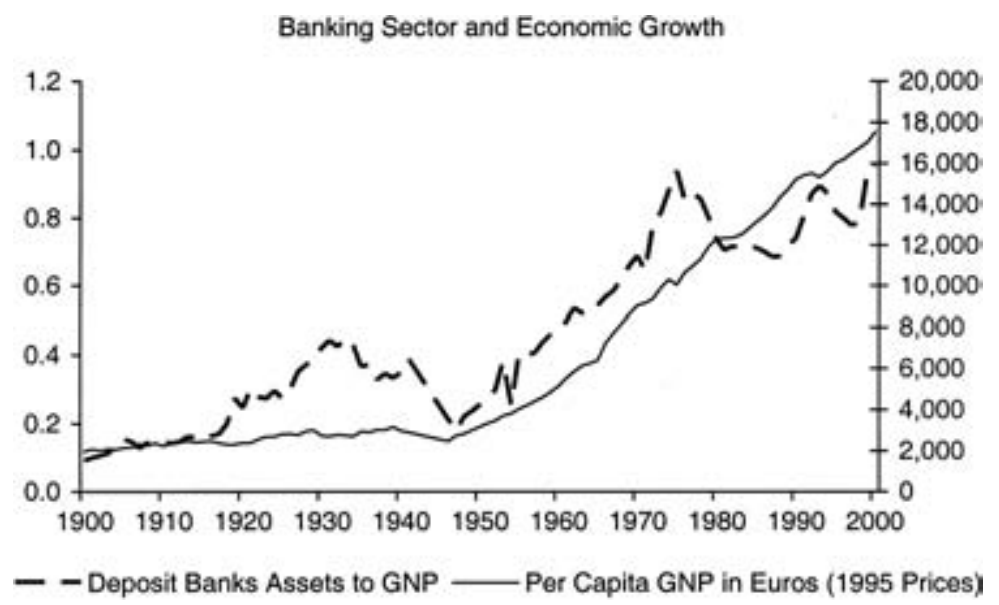

Fig. 6.4 Evolution of the ratio of deposit banks' assets to GNP and evolution of per capita GNP

Sources: Ciocca and Biscaini Cotula (1982), Rey (1991), and International Financial Statistics.

of the banking sector may be the answer. The growth in per capita GNP occurred at the same time as a similar expansion of the banking sector. The correlation of 91 percent exists between the ratio of deposit banks' assets to GNP and per capita GNP. The correlation of the growth in per capita GNP with stock market development is much lower: 3 percent if stock market development is measured as the number of traded companies to population and 22 percent if measured as the stock market capitalization to GNP.

\subsection{The Ownership Structure of Firms}

As shown by Barca (1994) and La Porta et al. (2000), high ownership concentration and pyramids characterize Italian corporate governance. Shleifer and Wolfenzon (2002) argue that high ownership concentration should be more common in countries with lower shareholder protection because of the inability of companies to sell equity to small shareholders when investors are not sufficiently protected by the law. Bebchuk (1999) points to the fact that control proves valuable in countries with low investor protection and therefore companies are closely held to ensure that control is not contestable. ${ }^{12}$ Wolfenzon (1998) argues that pyramidal

12. Within this second interpretation, countries with low shareholder protection should exhibit controlling shareholders. This, however, does not necessarily imply that there will be concentrated ownership. Indeed, there can be a lock on control even without a large owner. This can happen through cross-participation, shareholders' agreements, and powerful political connections. 
groups are created in order to expropriate shareholders, and this should occur more often in countries with lower investor protection. Bebchuk, Kraakman, and Triantis (1999) suggest the same empirical prediction by highlighting that pyramidal groups allow the separation between ownership and control without giving up control, which is a very important feature in a country in which control is very valuable.

\subsubsection{Investor Protection and Ownership Concentration}

Detailed data on ownership structure is available only from 1987 onward. Before 1987, only information on control can be found. ${ }^{13}$ The only exception is a booklet produced in 1948 by the trade union of the Communist Party, the CGIL, which documents the ownership structure of all Italian firms at the end of the Second World War.

Because of this data limitation, in this section, we compare the ownership structure of all companies traded on the MSE in three years: 1947, 1987 , and 2000. These years can be sorted by investor protection. According to our classification in three subperiods, investor protection was lowest in 1947, intermediate in 1987, and highest in 2000. Using the index of antidirector rights instead, antidirector rights equaled 2 in 1947 and 1987, and 5 in 2000. Table 6.4 compares six different measures of ownership concentration across these three samples.

The first measure is the fraction of voting rights owned by the largest shareholder. On average, the largest shareholder directly controlled about 45 percent of the votes in 1947, 55 percent in 1987, and 48 percent in 2000. According to this measure ownership concentration was higher in 1987 than in 1947 and 2000, while there was no difference between 1947 and 2000. This result suggests that ownership concentration has changed in a nonmonotonic fashion, first increasing and then decreasing.

The second measure is an indicator variable that takes a value of 1 if the company did not have a controlling shareholder (that is, if there was no shareholder with more than 20 percent of voting rights) and 0 otherwise. Excluding banks and insurance companies, no difference in this measure of ownership concentration existed over time. Only between 3.5 and 7.8 percent of the companies had no controlling shareholder. This result suggests that control was very valuable in all three years.

In companies with a controlling shareholder, one can reconstruct the chain of control and find the identity of the ultimate owner. The remaining four other indicators in table 6.4 characterize ownership concentration in companies with a controlling shareholder, that is, with a shareholder controlling at least 20 percent of the voting rights.

The number of voting rights controlled by the ultimate owner is the sum of all votes controlled both directly and indirectly by the ultimate owner in

13. See the appendix for a detailed description of this issue. 
Evolution of the ownership structure: Summary statistics

\begin{tabular}{|c|c|c|c|c|c|c|}
\hline & \multirow[b]{2}{*}{1947} & \multirow[b]{2}{*}{1987} & \multirow[b]{2}{*}{2000} & \multicolumn{3}{|c|}{ Tests (significant percentage level) } \\
\hline & & & & 1947 vs. 1987 & 1947 vs. 2000 & 1987 vs. 2000 \\
\hline No. of observations & 120 & 207 & 231 & & & \\
\hline \multicolumn{7}{|c|}{ Voting rights owned by largest shareholder (\%) [538 observations] } \\
\hline Mean & 44.58 & 55.46 & 48.00 & 1 & 0 & 1 \\
\hline Median & 48.65 & 54.14 & 52.11 & 1 & 5 & 1 \\
\hline \multicolumn{7}{|c|}{ Fraction of firms with no controlling shareholder (\%) [558 observations] } \\
\hline All companies & 10.00 & 4.35 & 12.99 & 5 & 0 & 1 \\
\hline $\begin{array}{l}\text { Excluding banks and } \\
\text { insurance companies }\end{array}$ & 7.76 & 3.53 & 5.62 & 0 & 0 & 0 \\
\hline \multicolumn{7}{|c|}{ Voting rights controlled by ultimate owner (\%) [494 observations] } \\
\hline Mean & 48.98 & 59.87 & 57.73 & 1 & 1 & 0 \\
\hline Median & 50.10 & 58.69 & 55.23 & 1 & 1 & 0 \\
\hline \multicolumn{7}{|c|}{ Cash-flow rights owned by ultimate owner (\%) [494 observations] } \\
\hline Mean & 40.38 & 42.11 & 51.31 & 0 & 1 & 1 \\
\hline Median & 44.10 & 47.00 & 52.92 & 0 & 1 & 1 \\
\hline \multicolumn{7}{|c|}{ Separation between ownership and control (voting rights/cash-flow rights) [494 observations] } \\
\hline Mean & 1.90 & 3.16 & 1.41 & 5 & 5 & 1 \\
\hline \multicolumn{7}{|c|}{ Pyramidal level [494 observations] } \\
\hline Mean & 1.43 & 1.86 & 1.31 & 1 & 0 & 1 \\
\hline
\end{tabular}

Notes: This table compares the mean and median ownership structure in traded companies across the three subsamples: 1947, 1987, and 2000. Six measures are used to characterize the ownership structure of a firm: the percentage of voting rights owned by the largest shareholders, the percentage of firms with no controlling shareholder (no shareholder controlling more than 20 percent of the votes), the percentage of voting rights controlled (directly or indirectly) by the ultimate owner, the percentage of cash-flow rights owned by the ultimate owner, the ratio of voting rights and cash-flow rights controlled by the ultimate owner, and the pyramidal level, that is, the number of traded companies along the chain of control, including the company itself. The last four variables are computed only for firms with a controlling shareholder. For each of these measures, the sub-sample means (medians) are compared across years using pair-wise tests of equality of means (medians). 0 denotes no significant difference. 1 denotes significance at the 1 percent level. 5 denotes significance at the 5 percent level.

a given company. This measure is significantly higher in 1987 and 2000 than in 1947. On average, the ultimate owner owned approximately 60 percent of the voting rights in 1987 and 2000 compared to approximately 50 percent in 1947.

The total sum of cash-flow rights owned by the ultimate owner is the product of the fractions of cash-flow rights along the control chain: it represents the exposure of the ultimate owner to the cash flows produced by the company. On average, cash-flow exposure increased over time: the ultimate owner owned about 40 percent of the cash flow rights in 1947, 42 in 1987, and 51 percent in 2000.

Separation between ownership and control is the ratio of voting rights controlled by the ultimate owner to his cash-flow rights. This variable also 
followed a nonmonotonic pattern. First it increased from 1947 to 1987, and then it decreased from 1987 to 2000.

Pyramidal level is the number of traded companies along the chain of control, including the company itself. This variable followed a nonmonotonic pattern as well. The degree of pyramiding was significantly higher in 1987 than in 1947, as many subsidiaries of traded companies went public during the stock market boom. The degree of pyramiding decreases in 2000 as many subsidiaries were taken private.

\subsubsection{Discussion}

Overall, there are three main conclusions from table (4): (a) between 1947 and 1987, ownership became more concentrated and there was an increase in pyramiding; (b) between 1987 and 2000, there was a reduction in ownership concentration and in pyramiding; and (c) across all samples there was no significant change in the fraction of widely held companies, which remained very rare.

Result (a) seems in contrast with the law and finance view. Indeed, an improvement in shareholder protection should decrease ownership concentration (Shleifer and Wolfenzon 2002) and pyramiding (Wolfenzon 1998). One obvious objection is that possibly there was no real change in investor protection between 1947 and 1987. Although several reforms were introduced in the 1970s, the index of antidirector rights did not change and so, probably, did enforcement. This argument does not explain why there was no pyramiding in 1947.

Result (b) is in favor of the law and finance view. Between 1987 and 2000, investor protection certainly improved. The 1990s were characterized by intensive regulation of traded companies and the stock market. The index of antidirector rights increased from 2 to 5. Consistent with Shleifer and Wolfenzon (2002) and Wolfenzon (1998), between 1987 and 2000 there was a significant decrease in ownership concentration and less pyramiding.

Result (c) is difficult to reconcile with law and finance. Indeed, the improvement in investor protection was not associated with any change in the fraction of MSE companies that are widely held. One obvious explanation is that enforcement has always been very poor and has not changed over time. If so, control remained equally valuable across time because the improvement of investor protection did not affect the value of control. But if there is no significant difference in effective investor protection across the three years, then how do we explain result (b)?

A possible concern with the methodology used in table 6.4 is that the results may be due to a composition effect. For instance, since the optimal ownership concentration may vary across industries, the variation observed in the data may be simply due to changing industry composition over time. In table 6.5 we evaluate the impact of the legal indicators after controlling for industry effects. The three main findings are substantially 
Evolution of ownership structure: Regressions

\begin{tabular}{|c|c|c|c|c|c|c|}
\hline & Constant & $\begin{array}{l}\text { Dummy } \\
\text { for } 1947\end{array}$ & $\begin{array}{l}\text { Dummy } \\
\text { for } 1987\end{array}$ & $\begin{array}{l}\text { Fixed } \\
\text { effect }\end{array}$ & $\begin{array}{c}\text { Adjusted } \\
R^{2}\end{array}$ & $\begin{array}{c}\text { No. of } \\
\text { observations }\end{array}$ \\
\hline \multicolumn{7}{|c|}{ Dependent variable: Voting rights owned by largest shareholder (\%) } \\
\hline (1) & $\begin{array}{l}48.25^{* * *} \\
(1.37)\end{array}$ & $\begin{array}{c}-5.74 * * \\
(2.63)\end{array}$ & $\begin{array}{l}8.00^{* * * *} \\
(2.00)\end{array}$ & Industry & 0.06 & 538 \\
\hline (2) & $\begin{array}{l}48.50^{* * * *} \\
(2.06)\end{array}$ & $\begin{array}{c}-2.84 \\
(5.03)\end{array}$ & $\begin{array}{c}5.82^{*} \\
(3.10)\end{array}$ & Group & 0.12 & 538 \\
\hline \multicolumn{7}{|c|}{ Dependent variable: Fraction of firms with no controlling shareholder (\%) } \\
\hline (3) & $\begin{array}{l}0.11 \text { *** } \\
(0.02)\end{array}$ & $\begin{array}{c}0.05 \\
(0.03)\end{array}$ & $\begin{array}{l}-0.08^{* * *} \\
(0.03)\end{array}$ & Industry & 0.12 & 558 \\
\hline (4) & $\begin{array}{l}0.09 \text { *** } \\
(0.03)\end{array}$ & $\begin{array}{c}-0.00 \\
(0.06)\end{array}$ & $\begin{array}{c}0.01 \\
(0.04)\end{array}$ & Group & 0.29 & 558 \\
\hline \multicolumn{7}{|c|}{ Dependent variable: Voting rights controlled by ultimate owner (\%) } \\
\hline (5) & $\begin{array}{l}57.74 * * * \\
(1.12)\end{array}$ & $\begin{array}{l}-9.25^{* * * *} \\
(2.16)\end{array}$ & $\begin{array}{c}2.33 \\
(1.59)\end{array}$ & Industry & 0.08 & 494 \\
\hline (6) & $\begin{array}{l}56.53^{* * * *} \\
(1.80)\end{array}$ & $\begin{array}{l}-6.12 * * * \\
(4.36)\end{array}$ & $\begin{array}{c}3.85 \\
(2.62)\end{array}$ & Group & 0.06 & 494 \\
\hline \multicolumn{7}{|c|}{ Dependent variable: Cash-flow rights owned by ultimate owner (\%) } \\
\hline (7) & $\begin{array}{l}51.26^{* * *} \\
(1.51)\end{array}$ & $\begin{array}{c}-11.40 * * * \\
(2.91)\end{array}$ & $\begin{array}{l}-8.68^{* * *} \\
(2.15)\end{array}$ & Industry & 0.07 & 494 \\
\hline (8) & $\begin{array}{l}43.49^{* * * *} \\
(2.00)\end{array}$ & $\begin{array}{c}-0.83 \\
(4.90)\end{array}$ & $\begin{array}{c}5.45^{*} \\
(2.89)\end{array}$ & Group & 0.36 & 494 \\
\hline & Dependent 1 & ble: Separat & tween owne & and contro & ting/cash-f & ghts) \\
\hline (9) & $\begin{array}{l}1.41^{* * *} \\
(0.23)\end{array}$ & $\begin{array}{c}0.55 \\
(0.44)\end{array}$ & $\begin{array}{l}1.67^{* * * *} \\
(0.32)\end{array}$ & Industry & 0.09 & 494 \\
\hline (10) & $\begin{array}{l}2.05^{* * * *} \\
(0.39)\end{array}$ & $\begin{array}{c}0.02 \\
(0.96)\end{array}$ & $\begin{array}{c}0.37 \\
(0.56)\end{array}$ & Group & -0.05 & 494 \\
\hline \multicolumn{7}{|c|}{ Dependent variable: Pyramidal level } \\
\hline (11) & $\begin{array}{l}1.29 * * * \\
(0.06)\end{array}$ & $\begin{array}{c}0.02 \\
(0.11)\end{array}$ & $\begin{array}{l}0.55^{* * * *} \\
(0.08)\end{array}$ & Industry & 0.12 & 558 \\
\hline (12) & $\begin{array}{l}1.53^{* * * *} \\
(0.08)\end{array}$ & $\begin{array}{c}-0.22 \\
(0.20)\end{array}$ & $\begin{array}{c}0.04 \\
(0.12)\end{array}$ & Group & 0.26 & 558 \\
\hline
\end{tabular}

Notes: This table compares the ownership structure in traded companies across the three sub-samples (1947, 1987 and 2000) while controlling for industry and groups fixed effects. Ownership structure is characterized by the six measures described in table 6.4. Regressions with fixed effects: robust standard errors are in parentheses.

***Significant at the 1 percent level.

**Significant at the 5 percent level.

*Significant at the 10 percent level.

confirmed. We also control for fixed effects at the group level, because different groups may have idiosyncratic reasons for choosing a specific ownership structure. For instance, pyramiding is likely to be more common in larger groups. In table 6.5, we find that the group fixed effects eliminate the differences in pyramiding.

Figure 6.5 describes the evolution of the control of traded companies 
Control Composition of Traded Companies (Market Value)

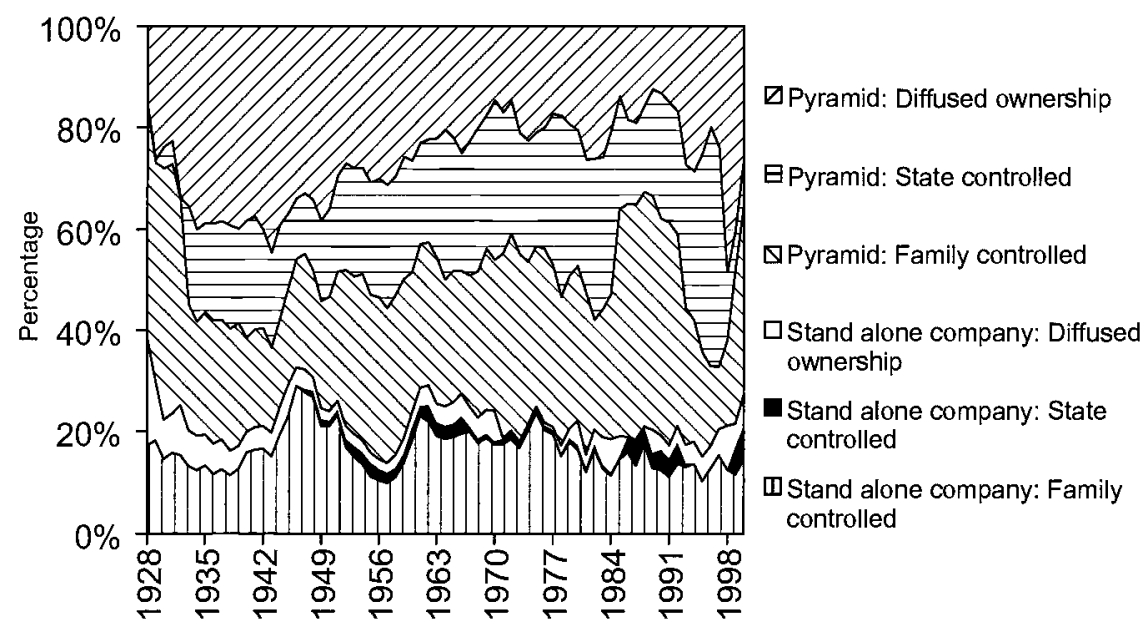

Fig. 6.5 Distribution of different types of control over time

Notes: The size of each class is based on its relative market value. First, we distinguish between stand-alone companies and members of pyramidal groups. Then, within each category, we separate state-controlled, family-controlled, and widely held companies depending on whether the ultimate owner is the government, a family, or dispersed shareholders, respectively.

over time. Firms are classified into six classes of control: first, we distinguish whether the firm is a stand-alone or belongs to a pyramidal group. Second, we differentiate between family, widely held, and state-controlled firms. The figure shows that stand-alone companies rarely counted for more than 30 percent of the market value of all traded companies. It is interesting to observe that from the Great Depression on, the importance of widely held pyramids steadily declined. This trend has been reversed only recently with the government's program of privatization. State- and family-controlled pyramids were the groups whose shares increased the most. Family-controlled pyramids represented 30 percent of market capitalization of MSE in 1950 and increased steadily to 40 percent in the middle 1980s. More recently, they declined to about 20 percent at the end of the 1990s. Government-controlled pyramids went from 0 to 20 percent of market capitalization of MSE during the 1930s and increased steadily to 40 percent by the end of the 1970s. By 2000, after the recent sweeping program of privatizations, they had almost disappeared.

The extent of pyramiding may be affected by the tax treatment of intercompany dividends (Morck 2003). The data on Italy do not support this explanation. Before 1955, dividend income was not taxable in Italy (with the exception of a few years during the fascist regime when dividend income was subject to taxes). Hence, no double taxation of intercompany 


\section{Average Pyramidal Level}

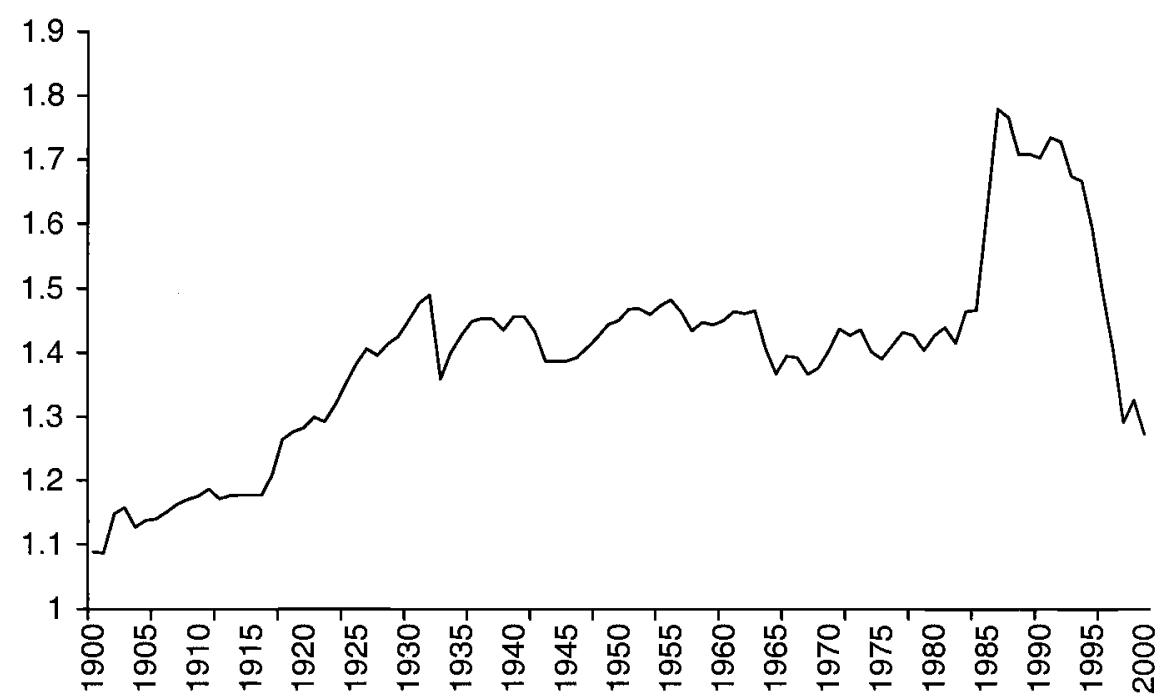

Fig. 6.6 Evolution over time of the average pyramidal level

Notes: All government-controlled firms are excluded. Pyramidal level is defined as the number of traded companies along the chain of control, including the company itself.

dividends existed. In 1955, Italy introduced a new tax on corporate income at an average rate of 18 percent, including surcharges. This additional tax was not deductible in the hands of recipient corporations and therefore discriminated against vertical groups. ${ }^{14}$ Under the general income tax reform of 1974, the additional tax burden on vertical groups further increased as intercompany dividend income became taxable at a 25 percent rate in the hands of a recipient company. However, pure holding companies became eligible for taxation of dividend income at a 7.5 percent rate. ${ }^{15}$ This tax regime changed in 1977, when the law introduced a tax credit for dividends that removed double taxation.

Since the treatment of intercompany dividends is the same in the three years $(1947,1987$, and 2000), taxes cannot explain the difference of pyramiding shown in table 6.4. More generally, the evidence is weak. Figure 6.6 shows that the introduction of double taxation in 1955 was not followed by any significant changes in pyramiding. ${ }^{16}$ Because there was no concurrent

14. Dividends were taxed both as corporate income of subsidiary and as dividend income of its parent.

15. Such favorable taxation of pure holding companies may explain why many Italian traded companies chose to present themselves as pure holdings on the stock market.

16. The steep drop in the average pyramidal level after 1962 was the result of rapid consolidation of former electrical companies after nationalization of electrical assets. 
change in shareholder protection or other aspects of the institutional environment, any changes in the degree of pyramiding can be largely attributed to the tax effect, which turns out to be very small. At the same time, the elimination of double taxation in 1977 was not followed by any significant increase in the number of subsidiaries traded on the Italian stock market. The steep increase in pyramids came only ten years later and can hardly (if at all) be attributed to the change in the tax regime.

So what caused the increase in pyramids in the 1980s? A tentative explanation to be addressed more carefully in future research is that the financial reforms of the second half of the 1970s and the beginning of the 1980s channeled new liquidity to the stock market. Because of the reforms, investors had found new faith in equity investment (for instance, via the newly established mutual funds). Companies took advantage of this liquidity to raise money via IPOs and carve-outs and grow. Very soon, this stock market boom came to a stop, and what was left was several pyramidal groups.

\subsection{Family Capitalism}

The three major family-owned companies in 1928 were Italcementi, a producer of cement owned by the Pesentis; Pirelli, a producer of rubber cables and tires owned by the Pirelli family; and FIAT, a car company owned by the Agnelli family. Their growth largely benefited from the market power enjoyed in their industries and protection from foreign competition. The insulation from foreign competition in their core sector partly continued after the war. Hence, these three major families diverted some resources to invest outside their core sectors, acquiring electric companies, real estate firms, banks, and insurance companies.

The history of these three family groups is remarkably similar. Italcementi was set up in 1865 by Carlo Pesenti I, Pirelli was founded in 1872 by Giambattista Pirelli, and FIAT was founded in 1899 by Giovanni Agnelli I. The first went public on the MSE in 1874, the second in 1922, and the third in 1924. Each of them soon acquired control of their product market with between 60 and 80 percent market share of the domestic market and then expanded outside their industry. The Pesentis invested in banks and insurance companies; the Pirellis expanded in the electric sector and abroad; the Agnellis mostly invested in the mechanical and electrical components sectors and in real estate.

In what follows we present in detail the evolution of the Pesenti group and discuss more generally the fortunes of the other families.

\subsubsection{Evolution of the Pesenti Group}

In 1865 Carlo Pesenti I established the first company of the Pesenti group, Italcementi, which went public on the MSE in 1874. The group be- 
gan to expand outside the cement industry in 1945, when Carlo II, grandson of the founder, took over what had become a very profitable and powerful cement group. According to Confederazione Italiana del Lavoro (CGIL; 1948), at the time Italcementi produced 60 percent of the cement in Italy. In the following decade, Italcementi made several diversifying acquisitions through a nontraded subsidiary, Italmobiliare. Turani (1980) and Galli (1984) argue that monopolistic profits enjoyed by the group in the cement industry partially financed the acquisitions, as well as the unlimited credit obtained through strong political connections with the ruling Christian Democratic party and the Vatican. By 1953, Italmobiliare had gained control of an important stake in a traded company producing machinery, Franco Tosi; after subscribing to its major capital increase, it had acquired a 38 percent controlling stake in a traded insurance company, RAS; and it had obtained indirect control of its traded subsidiary, l'Assicuratrice Italiana. In this early period, the group also owned several nontraded banks, including Banca Provinciale Lombarda and Credito Commerciale (a third bank, Ibi, was acquired in 1967).

In 1967, at the apex of its expansion, the Pesenti group's involvement spanned the cement industry, construction and real estate, the mechanical and automotive sector, banking, and insurance. At that time the Pesenti group was second in wealth only to the owners of FIAT group, the Agnellis. The expansion into such diverse industries, financed with high leverage, proved a very risky strategy. The first difficulty came in 1968, when Carlo II had to sell the control of a troubled car company, Lancia, acquired in 1960, to the Agnellis, at a considerable loss. A second problem arose in 1972 when Michele Sindona, a Sicilian banker, acquired control of 36.5 percent of Italcementi. This acquisition threatened the Pesentis' control of their empire and forced Carlo II to buy out Sindona. The leverage of the group further increased as a result of financing the buyout with loans from Banca Provinciale Lombarda, which was still controlled by Italcementi through the nontraded subsidiary Italmobiliare. In 1979, Carlo II had to fend off another takeover attempt, this time by the Agnelli group, which acquired control of 10 percent of Italcementi and also threatened the Pesentis' market power in the cement industry through the expansion of Agnelli's cement company Unicem. In order to strengthen control over the group, the Pesenti group decided to change its organizational structure. In 1979 Italcementi distributed its stake in Italmobiliare to its shareholders on the basis of one Italmobiliare share for every two Italcementi shares held. The operation led to a listing of Italmobiliare on the MSE in 1980. In the same year Italmobiliare acquired 50.22 percent of Italcementi's capital from the Pesentis and became the holding company for the newly formed group.

The huge amount of debt incurred during the previous three decades of expansion led to the group's implosion in the early eighties. In 1981 l'Assi- 
curatrice Italiana was delisted from the MSE after having been acquired by RAS in 1980; in 1984 the German group Allianz purchased a controlling stake in RAS. Credito Commerciale was sold to Monte dei Paschi di Siena in 1982, Ibi was sold to CARIPLO in 1983, and the group's last bank, Banca Provinciale Lombarda, was sold to San Paolo Group in 1984. Adding to its financial problems, Italmobiliare was also heavily involved in the notorious bankruptcy of Banco Ambrosiano, being its largest minority shareholder at the time of its collapse in 1982. Carlo Pesenti II died in 1984 during court proceedings against him and other executives of Italmobiliare for alleged fraud related to Banco Ambrosiano.

Carlo's son, Giampiero, who took control of the family business after Carlo's death, shaped the present of the Pesenti group. Under Giampiero, the group returned to its roots by refocusing on the cement industry. In 1987 Italcementi began trading publicly with two subsidiaries, Cementerie Siciliane and Cementerie di Sardegna, on a wave of investor optimism. By 1995 , a year of investor pessimism, both cementeries and the manufacturing company Franco Tosi were losing money. They were delisted from the MSE after merging with their respective holding companies in 1996 and 1997. Capital increases as well as a subsequent swap of shares of holding companies and subsidiaries financed their three buybacks. In 1997 Italcementi increased its presence in the cement industry by purchasing a controlling stake in cement company Calcemento, a former member of the bankrupt Ferruzzi group. This subsidiary merged with Italcementi two years later. Franco Tosi was taken private through a share exchange with its parent Italmobiliare the same year. The evolution of the group is summarized in table 6.6 and figure 6.7 .

Table 6.6 Evolution of the Pesentis' group

\begin{tabular}{lll}
\hline Event & Company & Year \\
\hline \multirow{2}{*}{ IPO } & Italcementi & 1874 \\
& Italmobiliare & 1979 \\
& Cementerie Siciliane & 1986 \\
\multirow{3}{*}{ Acquisition } & Cementerie di Sardegna & 1986 \\
& RAS & 1952 \\
Sale & Franco Tosi & 1953 \\
Going private (delisting) & Calcecemento & 1997 \\
& RAS & 1985 \\
& L'Assicuratrice Italiana & 1980 \\
& Cementerie Siciliane & 1996 \\
& Cementerie di Sardegna & 1996 \\
& Franco Tosi & 1997 \\
& Calcecemento & 1999 \\
\hline
\end{tabular}

Note: This table summarizes the corporate events affecting the structure of the group, distinguishing among IPOs, acquisitions, sales, and delistings. 

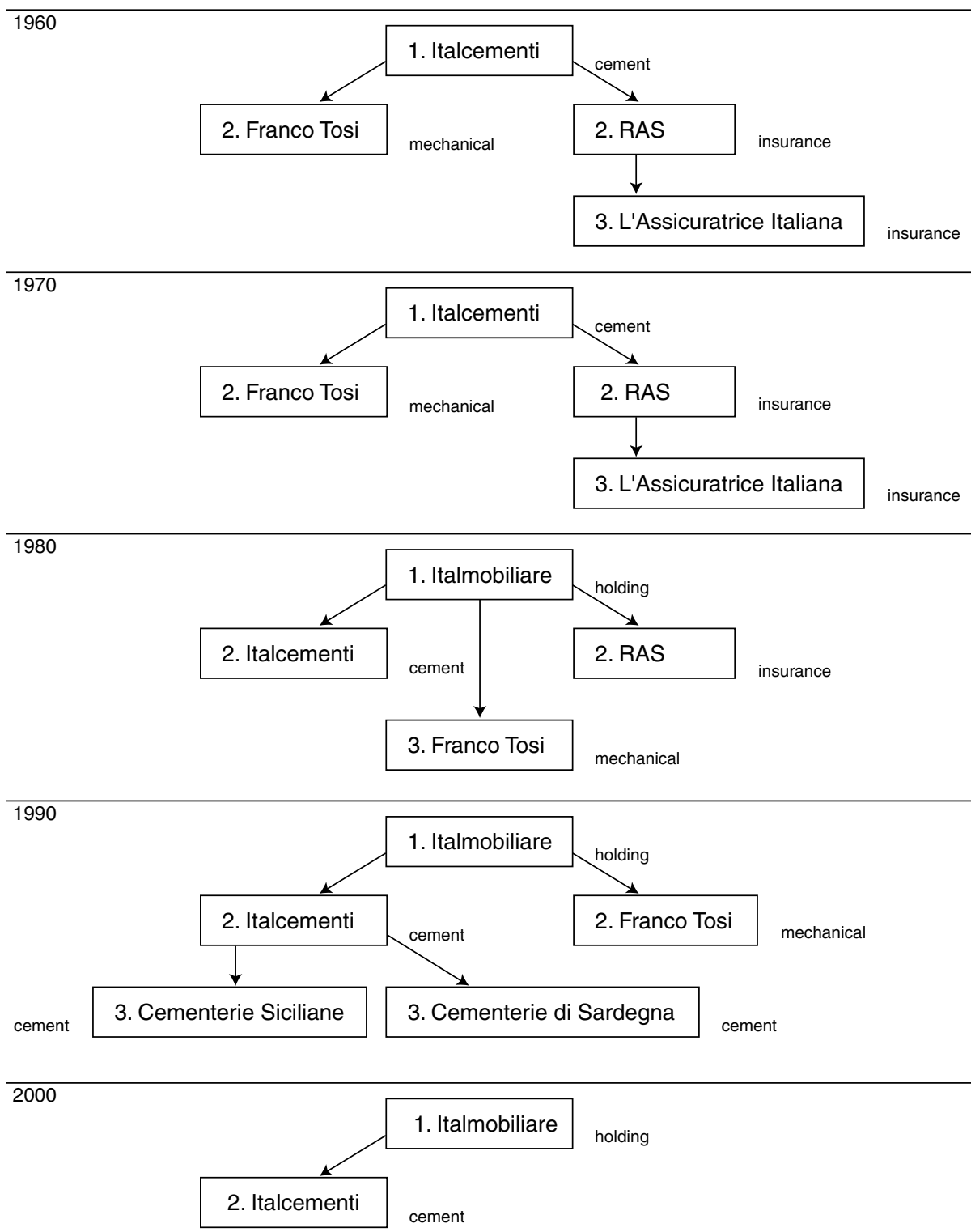

\section{Fig. 6.7 Evolution of the Pesenti group}

Notes: This figure shows the traded members of the Pesenti group and the structure of the group at ten-year intervals. Each box represents a traded company. An arrow denotes the chain of control. The number in the box denotes the pyramidal level. 


\subsubsection{General Findings}

In table 6.7, we show the ten largest groups as measured by market capitalization at the end of 1930 and at ten-year intervals until 2000. The names of groups controlled by families are designated with a superscript $b$. The names of government-controlled groups are designated with a superscript a. As one can immediately see, in 1930, only one family-controlled group appeared in the top ten: the Agnelli group. A large widely held investment bank, Banca Commerciale, headed up the largest group on the stock market. Several management-controlled public conglomerates also topped the chart. Among those, Edison was the largest holding company in the electricity sector and Montecatini controlled mining and steel. In 1940 after the collapse of Banca Commerciale, IRI, the governmentcontrolled agency created in 1933, was the largest group by market capitalization because it had taken over all companies previously controlled by Banca Commerciale. One new family made its appearance in the top ten, the Pirellis.

The presence of family groups in the top ten increased steadily, reaching four in 1960: together with Agnellis and Pirellis, we find Pesentis and Olivettis. Family-controlled groups controlled five of the top ten spots from 1970 to 1990 . A change in trend is evident in 2000, when only two family-controlled groups remained in the top ten: the Agnellis and the group controlled by Silvio Berlusconi.

A similar trend characterizes the evolution of the group controlled by Mediobanca, a secretive investment bank chaired by Enrico Cuccia that dominated Italian corporate finance through the second half of the century. Table 6.7 measures very ineffectively the power of Mediobanca in 1970s and 1980s. Because Mediobanca typically held minority stakes in traded companies and exercised significant influence through board seats and close relationships with creditor banks, it is difficult to quantify its influence.

Throughout the twentieth century, the Italian corporate governance system always had a reference point, a person or institution able to balance the interests of banks, families, and government. At the beginning of the century, Bonaldo Stringher and the Bank of Italy served as a reference point. From 1929 to the Second World War, the reference point was Alberto Beneduce and IRI. In the second half of the century, it was Enrico Cuccia and Mediobanca.

Table 6.7 confirms the view that family capitalism became important in the fifties and sixties and seems to have lost some ground since 1990. By contrast, widely held groups decreased in importance after the Great Depression and decreased in importance even more after the nationalization of the electricity industry when widely held conglomerates merged together and were taken over by the government. This trend reversed in the 
Table 6.7

The evolution of groups

\begin{tabular}{|c|c|c|c|c|c|}
\hline Group name & $\begin{array}{c}\text { No. of } \\
\text { companies }\end{array}$ & $\begin{array}{l}\text { MV } \\
(\%)\end{array}$ & Group name & $\begin{array}{c}\text { No. of } \\
\text { companies }\end{array}$ & $\begin{array}{l}\text { MV } \\
(\%)\end{array}$ \\
\hline \multicolumn{3}{|c|}{1930} & \multicolumn{3}{|c|}{1970} \\
\hline Banca Commerciale & 21 & 30.68 & $\mathrm{IRI}^{\mathrm{a}}$ & 18 & 29.30 \\
\hline Edison & 16 & 13.82 & Agnellib & 8 & 16.33 \\
\hline Montecatini & 5 & 4.46 & Montedison $^{\mathrm{a}}$ & 3 & 8.57 \\
\hline SADE & 6 & 4.34 & Generali & 1 & 5.92 \\
\hline Banca Italia $^{a}$ & 2 & 4.19 & Pesenti ${ }^{b}$ & 4 & 4.60 \\
\hline La Centrale & 3 & 3.96 & Bastogi & 7 & 3.19 \\
\hline Snia Viscosa & 8 & 3.75 & Pirellib & 2 & 2.61 \\
\hline Ligure Lombarda & 4 & 3.34 & $\mathrm{ENI}^{\mathrm{a}}$ & 4 & 2.03 \\
\hline Sme & 1 & 3.13 & Sindona ${ }^{\mathrm{b}}$ & 5 & 1.96 \\
\hline Agnellib & 3 & 2.10 & Olivetti $^{\mathrm{b}}$ & 1 & 1.94 \\
\hline C4 (\%) & 27.12 & 53.29 & C4 (\%) & 22.56 & 60.12 \\
\hline $\mathrm{C} 10(\%)$ & 38.98 & 73.77 & $\mathrm{C} 10(\%)$ & 39.85 & 76.45 \\
\hline \multicolumn{3}{|c|}{1940} & \multicolumn{3}{|c|}{1980} \\
\hline $\mathrm{IRI}^{\mathrm{a}}$ & 19 & 23.26 & $\mathrm{IRI}^{\mathrm{a}}$ & 18 & 25.20 \\
\hline Edison & 17 & 16.45 & Generali & 2 & 12.73 \\
\hline Montecatini & 5 & 9.09 & Agnellib & 8 & 8.14 \\
\hline La Centrale & 4 & 7.26 & Montedison & 10 & 7.84 \\
\hline SADE & 5 & 5.65 & Pesentib & 6 & 7.68 \\
\hline Bastogi & 6 & 4.46 & Ambrosiano & 5 & 5.55 \\
\hline Agnellib & 2 & 3.46 & Olivetti $^{\mathrm{b}}$ & 1 & 3.99 \\
\hline Snia Viscosa & 1 & 3.44 & Bonomi $^{b}$ & 7 & 3.59 \\
\hline Pirellib $^{b}$ & 3 & 2.96 & Mediobanca & 1 & 2.93 \\
\hline Ligure Lombarda & 5 & 2.66 & Ferruzzi $^{\mathrm{b}}$ & 3 & 2.87 \\
\hline C4 (\%) & 33.58 & 56.07 & C4 (\%) & 26.76 & 53.92 \\
\hline $\mathrm{C} 10(\%)$ & 50.00 & 78.69 & $\mathrm{C} 10(\%)$ & 42.96 & 80.52 \\
\hline \multicolumn{3}{|c|}{1950} & \multicolumn{3}{|c|}{1990} \\
\hline IRI $^{\mathrm{a}}$ & 16 & 17.37 & $\mathrm{IRI}^{\mathrm{a}}$ & 17 & 18.54 \\
\hline Edison & 11 & 15.04 & Agnelli ${ }^{\mathrm{b}}$ & 22 & 15.00 \\
\hline Montecatini & 3 & 8.48 & Generali & 2 & 11.44 \\
\hline La Centrale & 6 & 5.70 & Ferruzzib & 13 & 10.02 \\
\hline Snia Viscosa & 1 & 5.47 & $\mathrm{ENI}^{\mathrm{a}}$ & 9 & 5.99 \\
\hline Bastogi & 4 & 4.84 & De Benedetti ${ }^{\mathrm{b}}$ & 10 & 3.55 \\
\hline SADE & 6 & 4.72 & Ministero Tesoro ${ }^{\mathrm{a}}$ & 3 & 3.11 \\
\hline Agnellib & 3 & 4.12 & Mediobanca & 2 & 2.82 \\
\hline Pirellib & 4 & 3.34 & Pesenti ${ }^{b}$ & 5 & 2.39 \\
\hline Riva $^{\mathrm{b}}$ & 2 & 3.00 & Ligrestib $^{b}$ & 4 & 2.07 \\
\hline $\mathrm{C} 4(\%)$ & 27.69 & 46.59 & $\mathrm{C} 4(\%)$ & 23.68 & 55.00 \\
\hline $\mathrm{C} 10(\%)$ & 43.08 & 72.08 & $\mathrm{C} 10(\%)$ & 38.16 & 74.93 \\
\hline
\end{tabular}

(continued) 
Table 6.7

(continued)

\begin{tabular}{|c|c|c|c|c|c|}
\hline Group name & $\begin{array}{c}\text { No. of } \\
\text { companies }\end{array}$ & $\begin{array}{l}\text { MV } \\
(\%)\end{array}$ & Group name & $\begin{array}{c}\text { No. of } \\
\text { companies }\end{array}$ & $\begin{array}{l}\text { MV } \\
(\%)\end{array}$ \\
\hline \multicolumn{3}{|c|}{1960} & \multicolumn{3}{|c|}{2000} \\
\hline $\mathrm{IRI}^{\mathrm{a}}$ & 25 & 22.07 & Olivetti & 6 & 24.07 \\
\hline Edison & 12 & 14.28 & Generali & 3 & 10.20 \\
\hline Montecatini & 2 & 7.83 & $\mathrm{ENI}^{\mathrm{a}}$ & 3 & 7.59 \\
\hline Agnellib & 3 & 7.33 & ENEL $^{\mathrm{a}}$ & 1 & 6.55 \\
\hline La Centrale & 6 & 5.25 & Intesa & 4 & 5.48 \\
\hline Pirellib & 3 & 3.97 & San Paolo & 4 & 5.46 \\
\hline SADE & 7 & 3.53 & Unicredito & 3 & 4.89 \\
\hline Pesenti $^{\text {b }}$ & 3 & 3.42 & Berlusconi $^{\text {b }}$ & 3 & 3.61 \\
\hline Bastogi & 4 & 3.42 & Agnellib & 5 & 2.70 \\
\hline Olivetti ${ }^{\mathrm{b}}$ & 1 & 3.29 & Montedison & 7 & 2.28 \\
\hline $\mathrm{C} 4(\%)$ & 29.58 & 51.51 & $\mathrm{C} 4(\%)$ & 5.53 & 48.41 \\
\hline $\mathrm{C} 10(\%)$ & 46.48 & 74.39 & $\mathrm{C} 10(\%)$ & 16.60 & 72.83 \\
\hline
\end{tabular}

Notes: This table reports the name and the size (as measured by the number of traded companies and the market capitalization as a percentage of the stock market capitalization) of the ten largest groups present on the MSE at ten-year intervals from 1930 to 2000. For every year and each measure of size, two indices of stock market concentration are provided: $\mathrm{C} 4$ and $\mathrm{C} 10$ are respectively the size of the four and ten largest groups relative to the total market.

${ }^{\mathrm{a}}$ Government-controlled groups.

${ }^{\mathrm{b}}$ Family-controlled groups.

1980s and 1990s because of the government's massive privatization program. In 2000, large financial groups (Generali, Intesa, San Paolo, and Unicredito) and large conglomerates (Olivetti, ENI, ENEL, and Montedison) occupied the top positions.

The current crisis at FIAT symbolizes this revolution. But the transformation goes beyond the events in the Agnelli group. Interestingly, all three major family groups of the past have experienced significant changes in recent years. Pirelli came close to a financial collapse in the 1990s and was rescued by a manager, Marco Tronchetti Provera. Tronchetti Provera, who married into the Pirelli family and steered the group away from tires toward telecoms, is now the company's largest shareholder. The Pesenti group experienced financial distress in the 1980s and had to refocus on the cement sector by selling its controlling stakes in banks and insurance companies. The family still controls the group, although it has lost most of its economic influence. Finally, the Agnelli group might not survive the current crisis.

\subsubsection{Discussion}

So why did family capitalism persist for so long in Italy? Most likely the absence of regulatory intervention and the abundance of government corruption preserved the right conditions for family capitalism over time. 
During the entire twentieth century, there was virtually no change in the inheritance tax in Italy. Therefore, taxation did not change a family's incentives to sell controlling stakes. In contrast, the top rate of the inheritance duties in Britain increased to 80 percent in 1949. Colli, Fernandez Perez, and Rose (2003) argue that inheritance duties profoundly affected family firm behavior in Britain, causing a large increase in the number of companies going public. Similarly, no major external institutional shocks existed. Unlike in Japan at the end of the Second World War, the Americans did not engage in a reform of Italian capitalism. As discussed by Amatori (1997), the "Americanization" process in Japan led to the improvement of regulation and the dismantling of the zaibatsu, the large family groups. In Italy, due to a lack of regulatory changes, both family- and statecontrolled groups survived after the war.

In addition to a lack of regulatory changes, little change occurred in legal enforcement. Enriques (2003) shows that enforcement of the law has always been extremely poor in Italy. With poor enforcement, changes in investor protection impacted companies little. With low effective investor protection, controlling shareholders continued to enjoy large private benefits of control from generation to generation.

\subsection{Conclusion}

In recent years, Italian capitalism has shown signs of a historical transformation.

Since the 1980s the stock market has grown in significance for the Italian economy. Many important private companies, including Benetton, Luxottica, Campari, and De Longhi, now trade publicly. Many more are considering public listings. Furthermore, recent governments have been committed to a program of privatization and have engaged in a stream of reforms to improve investor protection.

At the same time, the control of the largest traded companies has become relatively more contestable. Currently, out of the top ten groups in terms of market capitalization, only the group led by Prime Minister Silvio Berlusconi is controlled with more than 30 percent of votes. The market for corporate control has become more active with the first successful hostile takeover in Italy occurring in 1999 (the takeover of Telecom Italia by Olivetti).

The banking sector is also undergoing a sensational transformation. Mediobanca no longer predominates as an underwriter and investment bank. A process of consolidation has created an oligopoly of universal banks.

Finally, investors have become more aware of corporate governance issues. As a consequence, several groups have begun simplifying their control structure by taking the holding companies in the intermediate layers of their pyramidal groups private. 


\section{Appendix}

\section{Description of the data}

This paper uses a unique set of yearly data on valuation, financials, and control structure of all companies traded on the MSE from 1900 to 2000. The data have been hand-collected from several sources.

The investment guide Indici e dati (Mediobanca, various years-b) serves as the main source of financial data and year-end market capitalization. Indici e dati covers most companies traded on the MSE and selected companies traded on small exchanges. Another investment guide, Guida dell'azionista (Credito Italiano, various years), was useful for this purpose because it reports some financial indicators for all companies traded on all Italian stock exchanges. Unfortunately, this source provides less information than Indici e dati on many key variables, most importantly, describing valuation of the companies: unlike Indici e dati, Guida dell'azionista shows only maximum and minimum yearly price instead of market values of the companies. In most cases we are able to correct this problem by calculating market value using share prices on the last day of December published in a Milan newspaper, Corriere della Sera, and the number of outstanding shares from Guida dell'azionista. Since Indici e dati does not have balance data after 1977, Guida dell'azionista and Calepino dell'azionista (Mediobanca, various years-a) serve as the source of financial data for the second half of the sample.

Taccuino dell' Azionista (SASIB, various years) is the primary source of information for control over the companies in the sample. This publication gives brief histories of the companies listed on the MSE every year. Most recent volumes (since 1987) also present data on exact shareholding breakdowns. Most traded Italian companies have majority shareholders controlling more than 20 percent of votes in recent years. This concentration of voting power makes our definition of control unambiguous in most cases. Before 1987, we have precise information on ownership of all traded companies only for 1947, from CGIL (1948). For all other years, we have reconstructed the chain of control that ends with the ultimate owner (a family, the state, or a widely held company), where we have used all available sources to track all transfers of controls however defined. One limitation of this approach is that the definition of control may vary across sources. However, the information for 1947 suggests that ownership has always been quite concentrated. Hence, we find it likely that the definition of control is consistent across sources for most firms. Since we prefer to be conservative in defining control, we assume that control rests in the hands of the most recent controlling shareholder unless we have explicit information otherwise. In some cases our sources describe the control structure as a coalition control or as a widely held company. The first usually corre- 
sponds to an agreement by a group of shareholders to exercise relative majority control through coordinated voting of stakes with combined share of votes less than 20 percent. No controlling shareholders or controlling coalitions exist in the second case. We do not distinguish the cases of coalition control from the cases of widely held companies in the analysis. An incomplete list of our sources on control is the following: Amatori and Brioschi (1997), Amatori and Colli (1999), Barca et al. (1997), Brioschi, Buzzacchi, and Colombo (1990), Chandler, Amatori, and Hikino (1997), Ciofi (1962), Colajanni (1991), De Luca (2002), Grifone (1945), Scalfari (1961, 1963), Scalfari and Turani (1974), and Turani (1980).

Companies are classified into sixteen industrial sectors: (a) food and agriculture; (b) banks; (c) cement, glass, and ceramics; (d) chemicals and pharmaceuticals; (e) communications; (f) construction and real estate; (g) editorial and paper; (h) electric; (i) electronics; (j) financial; (k) insurance; (l) mechanical; (m) metals; (n) textiles; (o) transportation, and (p) other industries.

\section{References}

Aleotti, Aldo. 1990. Borsa e industria, 1861-1989: Cento anni di rapporti difficili. Milan: Comunità.

Amatori, Franco. 1997. Growth via politics: Business groups Italian Style. In Beyond the firm: Business groups in international and historical perspective, ed. Takao Shiba and Masahiro Shimotani. Oxford: Oxford University Press.

Amatori, Franco, and Francesco Brioschi. 1997. Le grandi imprese private: Famiglie e coalizioni. In Storia del capitalismo italiano dal dopoguerra ad oggi, ed. Fabrizio Barca, 118-53. Rome: Donzelli Editore.

Amatori, Franco, and Andrea Colli. 1999. Impresa e industria in Italia. Venice, Italy: Marsilio Editori.

Baia Curioni, Stefano. 1995. Regolazione e competizione: Storia del mercato azionario in Italia (1808-1938). Bologna, Italy: Il Mulino.

Barca, Fabrizio. 1994. Assetti proprietari e mercato delle imprese. Vols. I and II. Bologna, Italy: Il Mulino.

Barca, Fabrizio, Francesca Bertucci, Graziella Capello, and Paola Casavola. 1997. La trasformazione proprietaria di FIAT, Pirelli e Falck dal 1947 ad oggi. In Storia del capitalismo italiano dal dopoguerra ad oggi, ed. Fabrizio Barca, 15584. Rome: Donzelli Editore.

Barca, Fabrizio, and Sandro Trento. 1997. La parabola delle partecipazioni statali: Una missione tradita. In Storia del capitalismo italiano dal dopoguerra ad oggi, ed. Fabrizio Barca, 186-236. Rome: Donzelli Editore.

Battilossi, Stefano. 2000. Financial innovation and the golden ages of international banking: 1890-1931 and 1958-81. Financial History Review 7:141-75.

Bebchuk, Lucian. 1999. A rent-protection theory of corporate ownership and control. NBER Working Paper no. 7203. Cambridge, MA: National Bureau of Economic Research.

Bebchuk, Lucian, Reinier Kraakman, and George Triantis. 1999. Stock pyramids, 
cross-ownership and dual class equity: The creation and agency costs of separating control from cash flow rights. NBER Working Paper no. 6951. Cambridge, MA: National Bureau of Economic Research.

Bhattacharya, Utpal, and Hazeem Daouk. 2002. The world price of insider trading. Journal of Finance 57:75-108.

Biais, Bruno, and Enrico Perotti. 2002. Machiavellian privatization. American Economic Review 92:240-58.

Bonelli, Franco. 1971. La crisi del 1907: Una tappa nello sviluppo industriale in Italia. Turin, Italy: Fondazione Luigi Einaudi.

Bragantini, Salvatore. 1996. Capitalismo all'italiana. Milan: Baldini \& Castoldi.

Brioschi, Francesco, Luigi Buzzacchi, and Massimo G. Colombo. 1990. Gruppi di imprese e mercato finanziario: La struttura del potere nell'industria italiana. Rome: Nuova Italia Scientifica.

Chandler, Alfred D., Franco Amatori, and Takashi Hikino, eds. 1997. Big business and the wealth of nations. Cambridge, UK: Cambridge University Press.

Ciocca, Pierluigi, and A. M. Biscaini Cotula. 1982. Interesse e Profitto. Bologna, Italy: Il Mulino.

Ciofi, Paolo. 1962. I monopoli italiani negli anni cinquanta. Rome: Editori Riuniti.

Colajanni, Napoleone. 1991. Il capitalismo senza capitale. Milan: Sperling \& Kupfer.

Colli, Andrea, Paloma Fernandez Perez, and Mary Rose. 2003. National determinants of family firm development? Family firms in Britain, Spain, and Italy in the nineteenth and twentieth centuries. Enterprise and Society 4:28-64.

Confederazione Italiana del Lavoro (CGIL). 1948. Struttura dei monopoli industriali in Italia. Rome: Ufficio Statistica, Casa editrice Progresso.

Credito Italiano. Various years. Guida dell'azionista: Ragguagli su tutte le azioni quotate in borsa e sulle societa emittenti. Genova, Italy: Credito Italiano.

De Luca, Giuseppe. 2002. Le società quotate alla borsa valori di Milano dal 1861 al 2000: Profili storici e titoli azionari. Milan: Libri Scheiwiller.

Dimson, Elroy, Paul Marsh, and Mike Staunton. 2001. Millennium book II: 101 years of investment returns. London: ABN-AMRO and London Business School.

Dittmar, Amy, Jan Mahrt-Smith, and Henry Servaes. 2003. International corporate governance and corporate cash holdings. Journal of Financial and Quantitative Analysis 38:111-33.

Dyck, Alexander, and Luigi Zingales. 2004. Private benefits of control: An international comparison. Journal of Finance 59:537-600.

Enriques, Luca. 2003. Off the books, but on the record: Evidence from Italy on the relevance of judges to the quality of corporate law. In Global markets, domestic institutions: Corporate law and governance in a new era of cross-border deals, ed. Curtis J. Milhaupt, 257-94. New York: Columbia University Press.

Galli, Giancarlo. 1984. Il romanzo degli gnomi. Milan: Rusconi.

Gerschenkron, Alexander. 1962. Economic backwardness in historical perspective. Cambridge, MA: Harvard University Press.

Goldstein, Andrea. 2003. Privatization in Italy 1993-2002: Goals, institutions, outcomes, and outstanding issues. CESifo Working Paper no. 912. Munich: CESifo.

Grifone, Pietro. 1945. Il capitale finanziario in Italia. Rome: Einaudi.

La Porta, Rafael, Florencio López-de-Silanes, and Andrei Shleifer. 1999. Corporate ownership around the world. Journal of Finance 54:471-517.

La Porta, Rafael, Florencio López-de-Silanes, Andrei Shleifer, and Robert Vishny. 1997. Legal determinants of external finance. Journal of Finance 52:1131-50.

1998. Law and finance. Journal of Political Economy 101:678-709.

2000. Agency problems and dividend policies around the world. Journal of Finance 55:1-33. 
2002. Investor protection and corporate valuation. Journal of Finance 57: $1147-70$.

Leuz, Christian, Dhananjay Nanda, and Peter D. Wysocki. 2003. Earnings management and investor protection. Journal of Financial Economics 69:505-27.

Mediobanca. Various years-a. Calepino dell'azionista. Milan: Mediobanca.

. Various years-b. Indici e dati relativi ad investimenti in titoli quotati nelle borse italiane. Milan: Mediobanca.

Morck, Randall. 2003. Why some double taxation might make sense: The special case of inter-company dividends. NBER Working Paper no. 9651. Cambridge, MA: National Bureau of Economic Research.

Nenova, Tatiana. 2003. The value of corporate voting rights and control: A crosscountry analysis. Journal of Financial Economics 68:325-51.

Pagano, Marco, Fabio Panetta, and Luigi Zingales. 1998. Why do companies go public? An empirical analysis. Journal of Finance 53:27-64.

Pagano, Marco, and Paolo Volpin. 2001. The political economy of finance. Oxford Review of Economic Policy 17:502-19.

Rajan, Raghuram, and Luigi Zingales. 2003. The great reversals: The politics of financial development in the 20th century. Journal of Financial Economics 69: $5-50$.

Rey, Guido. 1991. I conti economici dell'Italia, 1: Una sintesi delle fonti ufficiali 1890-1970. Rome: Edizione Laterza.

Rossi, Stefano, and Paolo Volpin. 2004. Cross-country determinants of mergers and acquisitions. Journal of Financial Economics 74:277-304.

SASIB. Various years. Taccuino dell'azionista: Annuario di documentazione finanziaria industriale e di borsa. Milan: Solé 24 Ore.

Scalfari, Eugenio. 1961. Rapporto sul Neocapitalismo in Italia. Bari, Italy: Editori Laterza.

1963. Storia segreta dell'industria elettrica. Bari, Italy: Editori Laterza.

Scalfari, Eugenio, and Giuseppe Turani. 1974. Razza padrona: Storia della borghesia di stato. Milan: Feltrinelli Editore.

Shleifer, Andrei, and Daniel Wolfenzon. 2002. Investor protection and equity markets. Journal of Financial Economics 66:3-27.

Siciliano, Giovanni. 2001. Cento anni di borsa in Italia. Bologna, Italy: Societa’ Editrice Il Mulino.

Turani, Giuseppe. 1980. Padroni senza cuore. Milan: Rizzoli.

Wolfenzon, Daniel. 1998. A theory of pyramidal ownership. Harvard University, Department of Economics. Mimeograph.

Wurgler, Jeffrey. 2000. Financial markets and the allocation of capital. Journal of Financial Economics 58:187-214.

Zingales, Luigi. 1994. The value of the voting right: A study of the Milan stock exchange experience. Review of Financial Studies 7:125-48.

\section{Comment Daniel Wolfenzon}

Italy is one of the best-known examples of a country in which pyramidal business groups dominate the corporate landscape. Aganin and Volpin's

Daniel Wolfenzon is assistant professor of finance at the Stern School of Business, New York University. 
paper tracks down the origin and evolution of these groups. They also document the history of financial development and ownership concentration in Italy in the twentieth century. In addition, the authors provide an interesting case study of the evolution of the Pesenti group.

The paper finds that the number of firms in the Milan Stock Exchange (MSE) has not been increasing monotonically. Instead, the number of publicly traded firms per inhabitant was higher in the beginning of the century than in the middle. This number starts increasing around the early 1980s and today is above the level it had in the beginning of the century. Other variables followed an inverted U-shaped pattern. Ownership was more concentrated in the middle part of the century than it was both in the beginning and in the end. Also, there were more pyramids between 1930 and 1980 than there were in the periods 1900-1930 and 1980-2000.

Aganin and Volpin explain these patterns using the effect of laws and the level of government intervention in the stock market. The law and finance view states that the number of listed firms is a positive function of the level of investor protection (La Porta et al. 1997) and that the opposite relation holds for ownership concentration and the level of pyramiding (Shleifer and Wolfenzon 2002; Almeida and Wolfenzon 2004). Because in Italy the level of protection afforded by the law has been increasing over the century but the actual patterns of the financial variables are U-shaped, it appears as if the law and finance view does not provide a full explanation for ownership and financial development patterns.

The paper proposes that the missing force shaping these patterns is government intervention in the stock market. The Great Depression caused a large number of listed firms to fail. This prompted the Italian government to intervene in the economy by bailing them out. The upshot was that the government kept a controlling stake in most of these failing firms. The paper argues that this massive government intervention in the stock market was the cause of the decrease in the number of listed firms. The role of the government started to decline in the 1990s due to the large privatization plan. In line with the political view, as the government withdrew from the stock market, the number of listed firms started to increase again.

Aganin and Volpin have done a fantastic job of putting together the facts with the potential explanations. Despite the fact that they analyze a single country and that there are essentially only two changes (one from the beginning of the century to the middle of the century and the other from the middle to the end of the century), they have done a careful job at looking at all other potential explanations.

I have two comments. First, I will argue that the law and finance view and the political view are not mutually exclusive theories but can be seen as two elements of a single mechanism. In my second comment I highlight what I believe are the most important aspects of the case study of the Pesenti group. I think we can draw many lessons from this case study to help 
us understand why business groups are formed and why they frequently adopt a pyramidal ownership structure.

My first comment relates to a unifying framework to think about the two views (law and finance and politics). In this framework politics shapes the government's incentives to improve or worsen investor protection, and the laws and regulations are just some of the tools that the government has at its disposal to achieve these changes. Thus, laws do affect investor protection (law and finance view), but the reason why these laws are in place can be traced back to the government's incentives (political view).

But how can it be that the incentives of the government do not always point to increasing the level of investor protection? Among other reasons, it could be that, with low levels of investor protection and the resulting poorly developed financial markets, talented potential entrants might not be able to set up firms due to lack of finance. Therefore, incumbents benefit from a low level of investor protection since it effectively acts as a barrier to entry. If incumbents have sufficient influence over policy decisions, investor protection will remain low. If, for some reason, incumbents lose their influence, investor protection has the potential to improve.

This is not a new idea. In a study of more than twenty countries over the twentieth century, Rajan and Zingales (2003) find a similar U-shaped pattern in financial development. They explain these patterns with the different incentives that incumbent industrialists and financiers faced throughout the century to either retard or accelerate the level of financial development (see also Morck, Yeung, and Wolfenzon 2004). Moreover, in a recent paper, Braun and Raddatz (2004) find that, following a shock to the political equilibrium, financial development improves only in countries in which the strength of the group of incumbents that benefit from financial development is higher than the strength of the group that is negatively affected by it. Interestingly, and confirming the unified theory of politics and law and finance, Braun and Raddatz point to specific policy reforms that caused the higher levels of financial development.

However, aren't these results inconsistent with the law and finance view that proposes an immutable link between investor protection and legal origin? I do not think so. In my opinion, the law and finance view (La Porta et al. 1998) makes three important contributions. The first one is that the rights of investors are not protected equally across jurisdictions and that differences in this protection influences corporate decisions, financial development, and a number of real variables. In fact, theoretical models in the law and finance tradition (e.g., Shleifer and Wolfenzon 2002; Burkart, Shleifer, and Panunzi 2003; Almeida and Wolfenzon 2004) simply require that there be differences in investor protection and are agnostic about the source of variation. These models are consistent with differences in investor protection arising from differences in the laws, but they are also consistent with differences arising from enforcement, quality of accounting, 
efficiency of the judiciary, and so on. The second contribution of the law and finance view is that differences in laws can explain a large fraction of the variation in investor protection. Finally, the third component is that these laws are highly correlated with the legal origin of the country. The combined law and finance and politics view I described is perfectly consistent with contributions one and two.

Going back to the case of Italy, how can we explain the U-shaped pattern in the level of financial development when the level of investor protection afforded by the laws was monotonically increasing throughout the century? After all, a strict reading of the framework I described suggests that the effects of government incentives to alter the level of investor protection should be summarized in the laws and then only these laws should affect the level of investor protection.

One potential answer is that the level investor protection afforded by the laws as measured in the paper does not capture all the relevant aspects of investor protection. This could be due to either one of the following possibilities: (a) that the authors, despite their formidable effort, might not be capturing all the relevant laws, or (b) that, in addition to the laws, there are other factors, like the level of enforcement, that determine investor protection. If the investor protection afforded by the laws as measured in the paper is not a sufficient statistic for the actual level of investor protection, then it is possible that other proxies of investor protection show up significantly in the regressions. One such proxy could be a measure of the government's incentives to maintain a low level of investor protection. It turns out that government involvement in the stock market is a good measure of these incentives. As the authors explain, during the period in which the Italian government had a significant presence in the stock market, it had no incentives to improve the level of investor protection. However, when the time came to privatize the state-owned enterprises, the government had strong incentives to provide the highest level of investor protection possible. As Aganin and Volpin find, including both the level of protection afforded by the laws and the level of government intervention in the stock market in the regressions leads to the right sign on the coefficient of investor protection.

My second comment relates to the case study of the Pesenti group. The paper documents how the group grew from a single firm to a very large organization composed of many independent firms in a period of roughly 130 years. Most of the time, new firms were added to the group as partial subsidiaries of existing firms, thereby creating a pyramid. The case study also documents the enormous financing needs of the Pesenti group.

There is an emerging literature trying to explain the existence of business groups and their ownership structure. We can draw a couple of lessons from this case study. First, groups are not formed instantly; rather, they grow over time, starting from a single firm. As a result, a theory of business 
groups and pyramids should incorporate these dynamic aspects. Thinking about business groups as the optimal organization form chosen at a single point in time is perhaps less realistic. Second, the Pesenti group needed a great deal of external finance to set up or buy new firms. Members of the Pesenti family could have avoided creating a pyramid by setting up these new firms and holding shares directly in them. However, this would have required raising even more external finance. Setting the firm up as a partial subsidiary (pyramid) allowed the family to tap the internal resources of the existing firms. Thus, pyramids emerge as a result of large financing needs and poorly developed capital markets. In a recent paper Almeida and Wolfenzon (2004) explain the creation of groups and the use of pyramidal ownership using these two elements: a dynamic framework and poor financial development.

\section{References}

Almeida, Heitor, and Daniel Wolfenzon. 2004. A theory of family business groups and pyramidal ownership. New York University, Stern School of Business. Working paper.

Braun, Matias, and Claudio Raddatz. 2004. Trade liberalization and the politics of financial development. University of California at Los Angeles and World Bank. Working paper.

Burkart, Mike, Andrei Shleifer, and Fausto Panunzi. 2003. Family firms. Journal of Finance 58:2167-2202.

La Porta, Rafael, Florencio López-de-Silanes, Andrei Shleifer, and Robert Vishny. 1997. Legal determinants of external finance. Journal of Finance 52:1131-50. 1998. Law and finance. Journal of Political Economy 106:1113-55.

Morck, Randall, Bernard Yeung, and Daniel Wolfenzon. 2004. Corporate governance, economic entrenchment and growth. NBER Working Paper no. 10692. Cambridge, MA: National Bureau of Economic Research.

Rajan, Raghuram, and Luigi Zingales. 2003. The great reversals: The politics of financial development in the twentieth century. Journal of Financial Economics 69:5-50.

Shleifer, Andrei, and Daniel Wolfenzon. 2002. Investor protection and equity markets. Journal of Financial Economics 66:3-27. 
